\title{
Review
}

\section{Advancing Photodynamic Therapy for Endodontic Disinfection with Nanoparticles: Present Evidence and Upcoming Approaches}

\author{
Rayyan A. Alfirdous ${ }^{1,2}$, Isadora M. Garcia ${ }^{3}{ }^{-}$, Abdulrahman A. Balhaddad ${ }^{1,4}{ }^{\oplus}$, Fabrício M. Collares ${ }^{3} \oplus^{\circ}$, \\ Frederico C. Martinho ${ }^{1,5}\left(\mathbb{D}\right.$ and Mary Anne S. Melo ${ }^{1,6, *(\mathbb{D}}$
}

1 Dental Biomedical Sciences Ph.D. Program, University of Maryland School of Dentistry, Baltimore, MD 21201, USA; ralfirdous@umaryland.edu (R.A.A.); aabalhaddad@umaryland.edu (A.A.B.); fmartinho@umaryland.edu (F.C.M.); mmelo@umaryland.edu (M.A.S.M.)

2 Department of Restorative Dental Sciences, Prince Abdulrahman Advanced Dental Institute, Riyadh 11564, Saudi Arabia

3 Department of Dental Materials, School of Dentistry, Federal University of Rio Grande do Sul, Rua Ramiro Barcelos, 2492, Rio Branco, Porto Alegre 90035-003, RS, Brazil; isadora.mgarcia@hotmail.com (I.M.G.); fabricio.collares@ufrgs.br (F.M.C.)

4 Department of Restorative Dental Sciences, College of Dentistry, Imam Abdulrahman Bin Faisal University, Dammam 34212, Saudi Arabia

5 Division of Endodontics, Department of Advanced Oral Sciences and Therapeutics, University of Maryland School of Dentistry, Baltimore, MD 21201, USA

6 Division of Operative Dentistry, Department of General Dentistry, University of Maryland School of Dentistry, Baltimore, MD 21201, USA

* Correspondence: Mmelo@umaryland.edu

check for

updates

Citation: Alfirdous, R.A.; Garcia, I.M.; Balhaddad, A.A.; Collares, F.M.; Martinho, F.C.; Melo, M.A.S. Advancing Photodynamic Therapy for Endodontic Disinfection with Nanoparticles: Present Evidence and Upcoming Approaches. Appl. Sci. 2021, 11, 4759. https://doi.org/ 10.3390/app11114759

Academic Editor: Ivana Miletić

Received: 21 April 2021

Accepted: 20 May 2021

Published: 22 May 2021

Publisher's Note: MDPI stays neutral with regard to jurisdictional claims in published maps and institutional affiliations.

Copyright: (c) 2021 by the authors. Licensee MDPI, Basel, Switzerland. This article is an open access article distributed under the terms and conditions of the Creative Commons Attribution (CC BY) license (https:// creativecommons.org/licenses/by/ $4.0 /)$.
Abstract: The persistence of microorganisms in the root canal system is one of the leading causes of root canal treatment failure. Root canal anatomy is complex, and it is often a challenge to obtain optimal disinfection. Biofilms of putative pathogens hidden inside dentin tubules and other root canal ramifications may limit current disinfection protocols. The search for additional disinfection of the root canal has been intensely carried out over the last twenty years. Antimicrobial photodynamic therapy (aPDT) is an adjunctive, conservative, non-selective bacterial kill approach. aPDT has been used to improve root canals disinfection without inducing bacterial resistance. This review focuses on the up-to-date aPDT performance and upcoming promising strategies for disinfection of the root canal system. First, we summarized the barriers encountered by photosensitizer (PS) and light delivery applied to root canal disinfection. Second, we compile the most updated clinical literature. A systematic search for scientific articles was conducted in PubMed, MEDLINE, SCOPUS, and EMBASE to screen the related in vivo studies about this theme. Third, we summarized and critically analyzed the current developments to overcome the aPDT limitations, and we revealed upcoming perspectives in this scoping literature review. We present a timely and opportune review article focusing on the significant potential of aPDT in endodontic disinfection. aPDT offers multiple capabilities that may be considered toward the root canal system's disinfection with future outlooks in nanosized-platforms' design and performance.

Keywords: infection control, dental; dental pulp diseases; photosensitizing agents; dental care; microbiology; biofilms

\section{Introduction}

Root canal infections are initially treated by removing the infected tissues and disinfecting the root canal system with instrumentation and irrigation protocols. After that, clinicians perform an adequate root canal and apical sealing with the obturation and place an appropriate coronal sealing with a permanent restoration [1]. The root canal treatment usually saves the tooth and clears the infection; however, endodontic treatment can still fail [2]. Different factors have been identified as contributors to endodontic treatment failure, such as untreated or 
inadequate filling of the canals. However, pathogenic biofilms' persistence after the standard disinfection has been strongly attributed to endodontic failure and is known as one of the prime causes of unsuccess [3]. The presence of biofilms of putative pathogens trapped inside dentinal tubules, its ramifications and its relation with the recurrence of clinical symptoms and presence of periapical radiolucency is well reported in the literature [4]. The geometry of dentinal tubules with a narrow lumen (1-2 $\mu \mathrm{m})$ and considerable length $(2-3 \mathrm{~mm})$ challenge the disinfection. Previous reports have shown bacterial migration into dentinal tubules of the root at a depth of approximately 360-420 $\mu \mathrm{m}$ [5].

In contrast, the irrigating solution, most commonly, sodium hypochlorite $(\mathrm{NaOCl})$, has penetrability into dentinal tubules of approximately $130 \mu \mathrm{m}$. Over and above, the quantification of penetration of the photosensitizer (PS) Toluidine Ortho Blue (TBO) into the dentin substrates via confocal Raman micro-spectroscopy noted the maximum depth of penetration of 45-60 $\mu \mathrm{m}$ [6]. As illustrated in Figure 1, using confocal laser scanning microscopy, viable bacterial cells of E. faecalis strain, labeled to show fluorescence in blue, penetrate deep into the dentinal tubules.

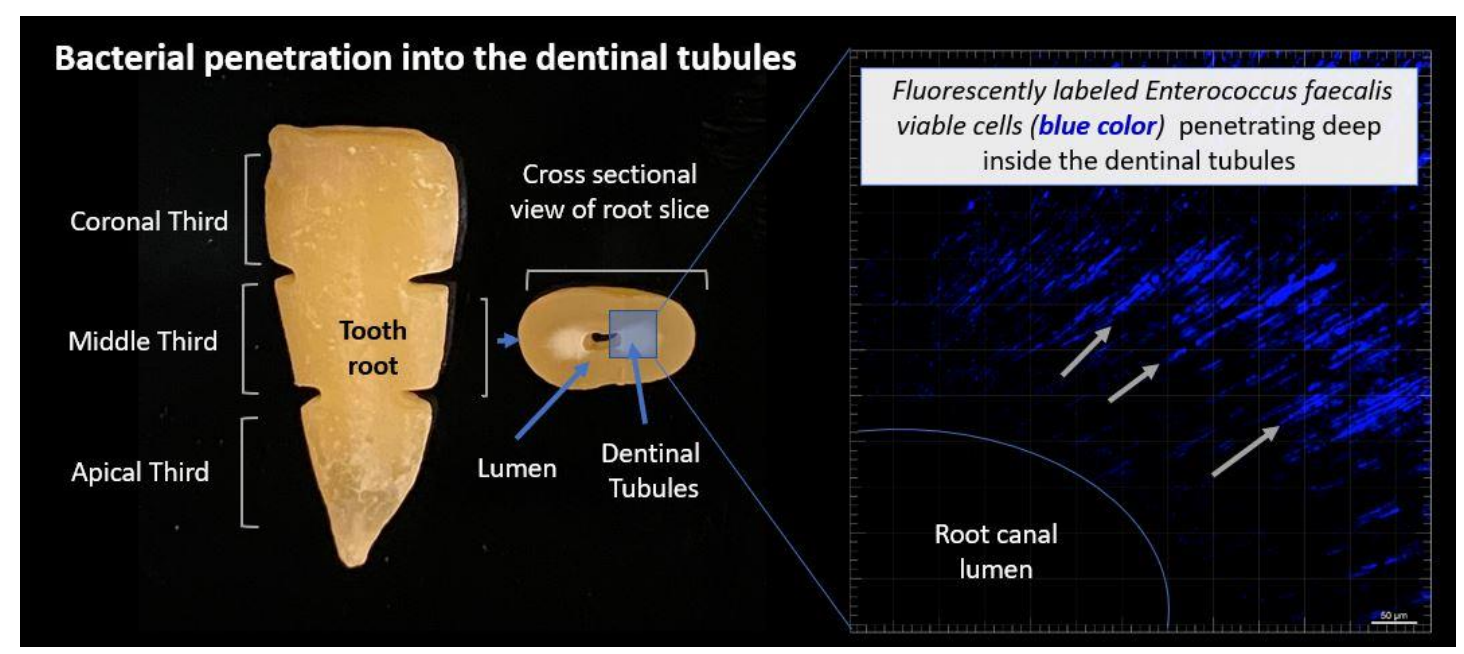

Figure 1. Representative confocal microscopic image of Enterococcus faecalis colonizing inside dentinal tubules $(20 \times$ magnification) may complicate the chemo-mechanical disinfection of root canal therapy.

The root canal system is very complex with an isthmus, lateral canals, accessory canals, and root canal ramifications [7]. Such complexity offers a challenge for optimal disinfection of the root canal system. These areas of isthmus and ramifications can harbor putative pathogens that may evade the antimicrobial activity of conventional disinfection protocols, including instrumentation and irrigation of the canals with auxiliary chemical substances. Previous investigations have shown that conventional root canal therapy is limited to $44 \%$ to $70 \%$ of disinfection [6,8]. Moreover, studies, using culture-dependent approaches, have indicated bacterial growth after root canal disinfection completion [9].

Limited putative pathogens can survive in the root canal system with the lack of nutrients after the endodontic treatment [10]. E. faecalis is a Gram-positive bacterium that is frequently recovered from persistent endodontic infections [11]. E. faecalis is detected in $33 \%$ of persistent endodontic infections [12]. This pathogen can be found as a monoculture in root canals with failed treatment [13]. E. faecalis has unique characteristics to survive, even after disinfection. This pathogen can penetrate the dentinal tubules, persist in a low-nutrient environment and $\mathrm{pH}$, resist high salinity and temperatures, survive even with the presence of intercanal medications and irrigants, develop antibiotic resistance, and form biofilms in medicated canals [14].

Overall, the complexity of the root canal system and the current infection protocols offer a challenge for the success of root canal therapy. Therefore, dentist-scientists are constantly searching for additional disinfection approaches to improve root canal disinfec- 
tion. Antimicrobial photodynamic therapy (aPDT) has been proposed as a supplemental approach to optimize root canal disinfection. In this manuscript, we conducted a scoping review with a systematic search of the literature, using PubMed, MEDLINE, SCOPUS, and EMBASE to screen the related in vivo studies. We summarized and critically analyzed the current developments to overcome the aPDT limitations, and we reveal upcoming perspectives along with this review.

\section{Overview of Chemo-Mechanical Disinfection and Current Intracanal Medications}

Endodontic treatment involves a chemo-mechanical approach to eliminate the infected tissues and disinfect the root dentin [15]. In a single-visit treatment appointment, the infected tissues are removed using rotary file systems called "intracanal instrumentation." Around $35 \%$ of the intracanal walls may remain intact after the instrumentation, reflecting in remaining infected tissues [16]. This scenario mandates combining the mechanical instrumentation and irrigation of the canals, using a sodium hypochlorite $(\mathrm{NaOCl})$ solution [17] $\mathrm{NaOCl}$ irrigation is not only helpful to disinfect the canals, but also to eliminate endotoxins produced by the putative endodontic pathogens $[1,18]$. Free chlorine in $\mathrm{NaOCl}$ irrigation can dissolve necrotic tissues by breaking down proteins into amino acids [19]. Consistent exchange and the use of a large volume of irrigation are recommended to maintain the antibacterial effectiveness of $\mathrm{NaOCl}$ [20].

Although robust bacterial reduction was gained, using instrumentation and irrigation, efficient disinfection of the root canal system is still not reached. As mentioned earlier, specific anatomic landmarks and the complexity of the formed biofilms may limit this chemo-mechanical approach's effectiveness [3,21,22]. E. faecalis can penetrate dentinal tubules to a deep extent, escaping from instrumentation and irrigation [23]. Another approach used to increase bacteria reduction is the use of antibacterial intracanal medications. These medications are applied inside the root canal and left to act between the two visits to increase the endodontic treatment's success rate [24,25].

Calcium hydroxide $\left(\mathrm{Ca}(\mathrm{OH})_{2}\right)$ is the most commonly used intracanal medication in endodontic treatment. $\mathrm{Ca}(\mathrm{OH})_{2}$ reduces the bacterial content via the cell layer's damage by direct contact and increasing the $\mathrm{pH}$ [26]. Even though it has a wide range of antibacterial activity, calcium hydroxide is not effective against $E$. faecalis $[7,8]$. Its proton pump enables E. faecalis to resist high $\mathrm{pH}$ [8] and grow in the presence of calcium hydroxide [7]. Moreover, E. faecalis can invade tubules and bind to collagen [6], depending on environmental signals to regulate its genetic expression [9]. Therefore, two-visit appointments with calcium hydroxide as intracanal medication does not show better periapical healing results, as $E$. faecalis can be recovered after the treatment $[10,11]$.

Chlorhexidine (CHX) at $2 \%$ was found more effective against $E$. faecalis than $\mathrm{Ca}(\mathrm{OH})_{2}$ [12]. However, there is no further bacterial reduction when compared to chemo-mechanical instrumentation. In this context, the use of antibiotics as intracanal medications is recommended. However, antibiotics' diffusion through the root canal may not be sufficient to inactivate bacteria [27]. Several investigations found that antibiotics could not fully eradicate pathogens inside the root canal system [13,14]. In addition, bacterial resistance development following the use of antibiotics is a rising concern among dentists. In the United States alone, around 2 million individuals are affected by infectious disease owing to bacterial resistance, resulting in 20,000 deaths annually [28]. Therefore, more efforts should be directed to explore and design other approaches that replace antibiotic use in targeting dental pathogens.

\section{Antimicrobial Photodynamic Therapy (aPDT)}

Antimicrobial Photodynamic Therapy (aPDT) is an adjuvant technique used to improve root canal disinfection without inducing bacterial resistance [29]. In this technique, a light at a specific wavelength is used to activate PSs, generating reactive oxygen species (ROS) [30]. The aPDT mechanisms are mainly divided into Type I and Type II, as shown in Figure 2. 


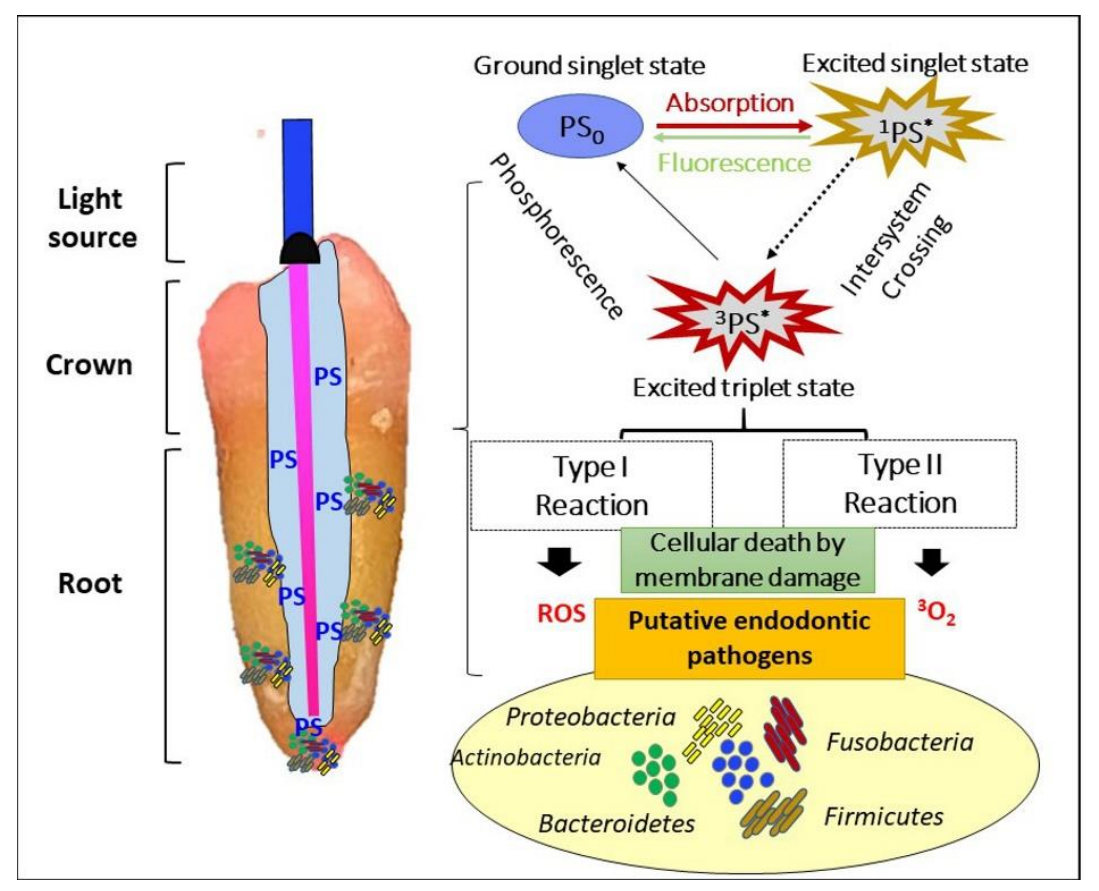

Figure 2. A light source with a specific wavelength can activate a photosensitizer to an excited singlet state and then to a triplet singlet state in antimicrobial photodynamic therapy. The triplet singlet state can induce antimicrobial killing via the generation of the reactive oxygen species (Type I), singlet oxygen (Type II), or both.

Type I: The light-excited PS interacts with the surrounding molecules by an electron or a hydrogen atom exchange. This process triggers specific environmental changes that lead to hydroxyl radicals, one of ROS's responsive forms [31]. After light activation of the PS, a series of released oxygen ions and free radicals kill the targeted cells [32,33]. One of the significant advantages of aPDT is the reliance on the enhanced penetration and accessibility of the reactive oxygen species [34,35].

Type II: Similarly, the PS is activated by light and reacts with the ground state molecular oxygen, generating excited singlet-state oxygen $\left({ }^{1} \mathrm{O}_{2}\right)$ that directly targets biofilmtriggered diseases [36]. Both types of reactions could happen simultaneously. The ratio between these mechanisms depends on the type of PS used and the PS molecules' microenvironment $[31,37]$.

The photosensitizers that were studied for the elimination of microorganisms belong to different classes of compounds: phenothiazinium derivates, such as toluidine blue and methylene blue; porphyrin [36] as described in Table 1; phthalocyanine derivatives (disulphonated aluminum phthalocyanine and cationic Zn(II)-phthalocyanine) [37]; halogenated xanthenes derivates, such as Rose Bengal; triarylmethane dyes, such as Malachite green, acridines; some conjugates of chlorins; and perylenequinones, such as hypericin [37]. However, the most used class for aPDT in endodontics is phenothiazinium derivates, such as toluidine blue and methylene blue. 
Table 1. General features of main photosensitizers used in aPDT against oral bacteria.

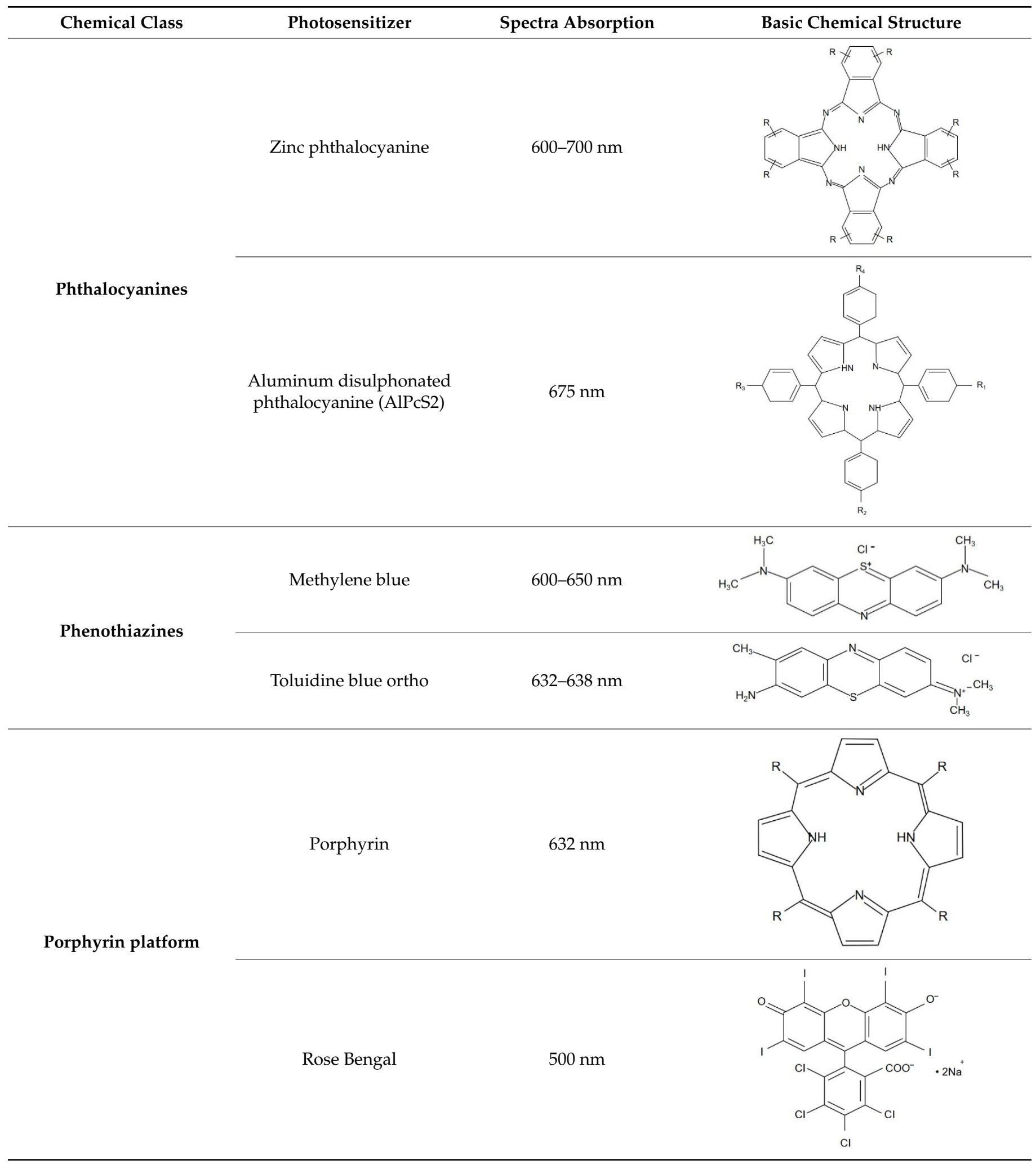


Table 1. Cont.

Chlorophyll platform Chloryns
Chloryn e6

$645-675 \mathrm{~nm}$

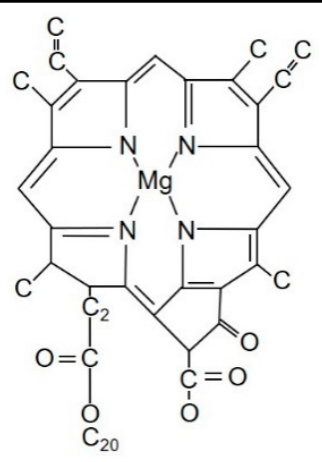

Most of them possess intense absorption bands in the red end of the visible spectrum $(¥>600 \mathrm{~nm}$ ). The absorption in red provides a relatively high penetration power in most human tissues and is not substantially absorbed by endogenous cell/tissue constituents, thus minimizing the risk of undesired side effects [38]. Differences in antibacterial action concerning the phenothiazinium photosensitizers are known for toluidine blue $\mathrm{O}(\mathrm{TBO})$ and MBO. Against E. coli, TBO is known to be membrane active since it interacts more easily with the bacterial membrane than the methylene blue because this dye presents great solubility in the hydrophobic region of the membrane. This dye's efficient antibacterial photoactivity causes increased permeability, whereas MB causes strand breaks in the organism's nucleic acid. These two compounds present physico-chemical structures and properties that are similar, but the photodynamic efficiency varies between different microorganisms.

In the early $2000 \mathrm{~s}$, aPDT has become more exciting and promising in the dental field as a non-to-minimally invasive approach [38]. The reasonable easy access to the oral cavity by the light source/PS solution and the effective killing of putative pathogens in vitro have granted clinical investigations in many dental specialties, such as periodontics, cariology, and endodontics [39] over the last twenty years. By 2013, the field of endodontics effectually started to experience rapid growth in the aPDT investigations, as described in Figure $3 \mathrm{~A}$. However, aPDT still has a long path to reach the status of standard care. In our up-to-date evidence synthesis, aPDT lacks much high-level evidence, as shown in Figure 3B, where only approximately $10 \%$ of the studies reported are randomized clinical trials.

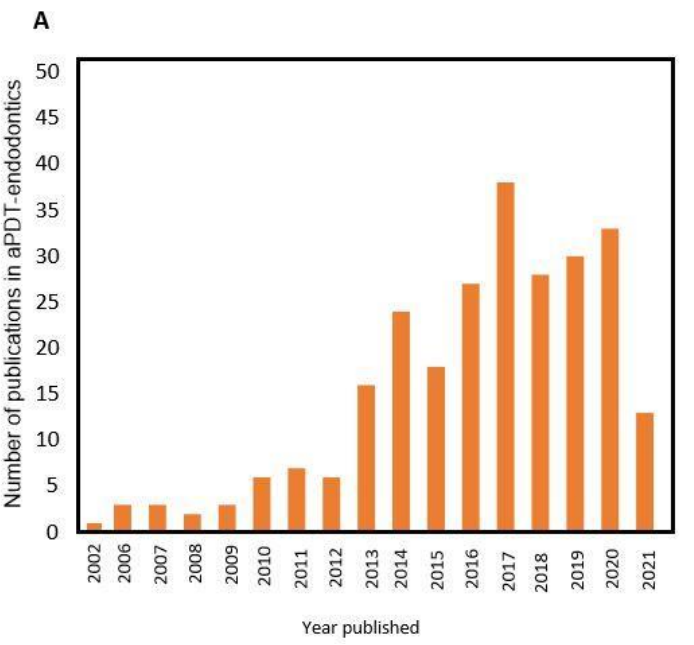

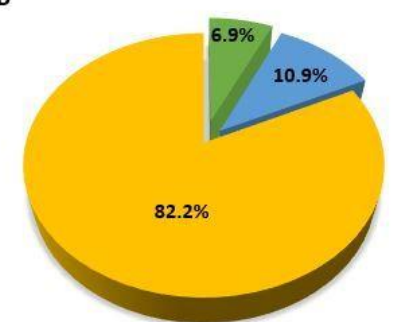

In vitro studies

Reviews

Clinical trials

Figure 3. (A) Over time, the number of publications containing the term "antimicrobial photodynamic therapy AND endodontics" via the searched database and (B) hese data represent a synopsis of aPDT investigations in the endodontic literature and reviews in the subject. 
In a complementary therapeutic context, aPDT applied to oral biofilm-related diseases brings to the dental field three inherent relevant advantages. First, dual site-specificity in which only the target cells that uptake the PS and are irradiated are compromised. Consequently, non-irradiated tissues will not show toxicity issues. Furthermore, PSs characteristically do not exhibit toxicity in the dark, which does not trigger the bacteria to participate in adaptive survival mechanisms against the PSs [40]. Second, the repeated protocol for aPDT with multiple applications per session does not promote bacterial resistance against the PSs. The timeframe for the photo process to occur is too short. In addition, it is difficult for the bacteria to note the upcoming oxidative stress provided by the photo process and create a defensive mechanism, such as the antioxidant defense [41]. Third, after the photo-oxidative attack, the bacteria are too weak to activate their crossgeneration adaptivity [41].

\section{4. aPDT Performance Based on In Vitro Studies}

Laboratory outcomes are promising for aPDT against several oral microorganisms, such as Streptococcus mutans, Fusobacterium nucleatum, Porphyromonas gingivalis, and Prevotella intermedia $[42,43]$. This approach opens the doors to investigate the effectiveness of aPDT against putative endodontic pathogens. Figure 4 shows the clinical protocol of aPDT applied to complement the disinfection of the root canal. The reported literature covers either in vitro studies where the therapy was applied against planktonic cultures of endodontic pathogens strains or monospecies biofilms, or studies where the aPDT effectiveness was assessed against endodontic bacterial strains grown inside root canals of extracted teeth. These in vitro studies explored the potential effect of aPDT against specific putative endodontic pathogens (mainly E. faecalis) and provide optimal parameters as a variable controlled in this type of designed study. The in vitro outcomes can pave the way for well-designed clinical studies and help support any discussion on the biological plausibility of aPDT, but they offer a low level of scientific evidence.

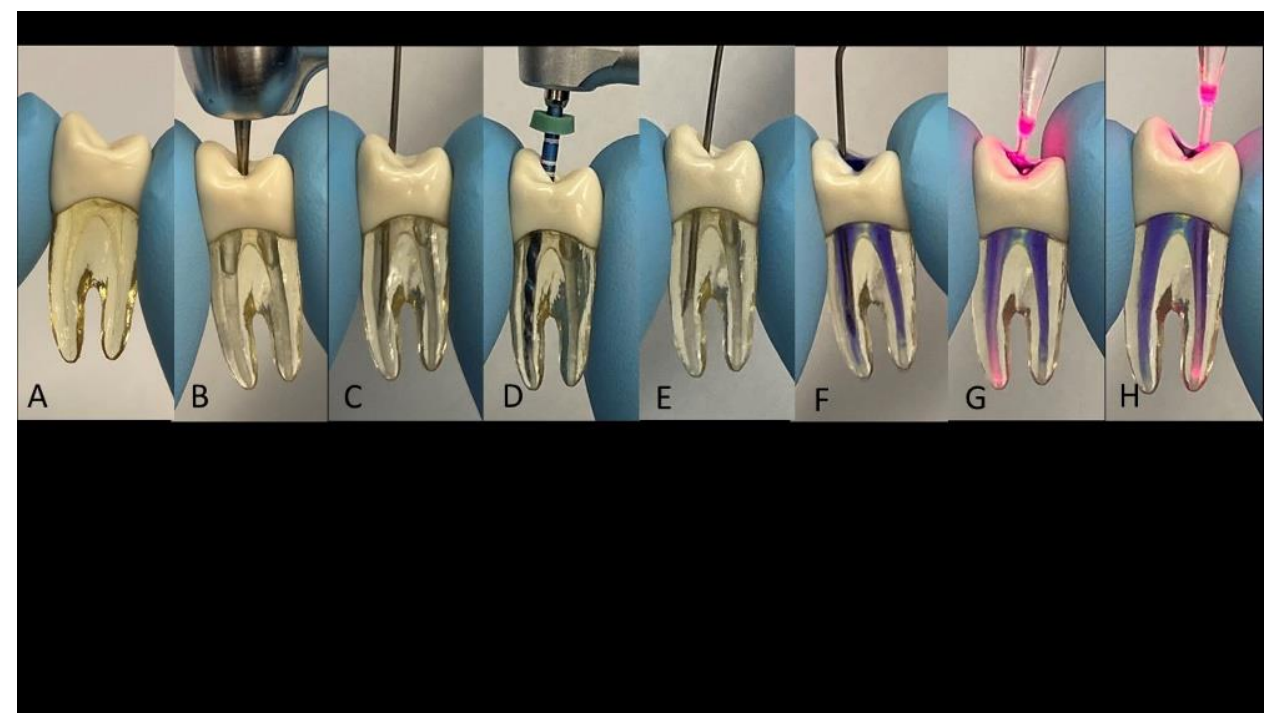

Figure 4. Schematic sequence of the antimicrobial photodynamic therapy clinical protocol applies for root canal disinfection. (A) Pre-treatment tooth diagnosis with infected canals. (B) Access to root canal system to remove the infective pulpal tissues. (C) Chemical debridement and irrigation with $2.5 \%$ of sodium hypochlorite $(\mathrm{NaOCl})$. (D) Mechanical instrumentation using rotary files to remove the infective radicular dentine. (E) A final rinse with $0.9 \%$ of saline. (F) A photosensitizer applied inside the canal for $1 \mathrm{~min}$. (G,H) A red light-emitting diode (LED; $660 \mathrm{~nm} ; 200 \mathrm{~mW}$ ), used to activate the photosensitizer. 
Consequently, one of the pioneers in in vitro studies was conducted in 2002, where Streptococcus intermedius biofilms were grown inside the root canal of extracted teeth for $48 \mathrm{~h}$ [44]. Toluidine Blue Ortho (TBO) at concentrations of 12.5, 25, 50, and $100 \mu \mathrm{g} / \mathrm{mL}$ was used to disinfect the root canal, using different energy doses ranged between 2.1 and $21 \mathrm{~J} / \mathrm{cm}^{2}$. It was found that the concentration of the PS and light dosimetry are determinants concerning the antibacterial reduction. aPDT using TBO was found effective in reducing the $S$. intermedius biofilm by around 5-log [44].

Azulene-based paste $(25 \mu \mathrm{g} / \mathrm{mL})$ as a PS and at an energy dose of $1.8 \mathrm{~J} / \mathrm{cm}^{2}$ was found to inhibit the E. faecalis biofilm [45]. aPDT using chlorine and polyethyleneimine along with the root canal treatment was more effective than each approach alone in inhibiting the growth of Proteus mirabilis and Pseudomonas aeruginosa [46]. The importance of the PS's concentration can be observed in another study where the effectiveness of $6.25 \mu \mathrm{g} / \mathrm{mL}$ of methylene blue ortho (MB), combined with an energy density of $30 \mathrm{~J} / \mathrm{cm}^{2}$, against $E$. faecalis biofilm was limited to $<1-\log$ reduction [47]. However, MB applied at a high concentration of $100 \mu \mathrm{g} / \mathrm{mL}$ combined with an energy dose of $16.2 \mathrm{~J} / \mathrm{cm}^{2}$ promoted an around 2.5$\log$ reduction [48]. It worth noting that the applied energy density is approximately half of the value in the previous study. This outcome highlights the relevance of PS concentration selection.

Often, in vitro studies evaluate aPDT against early-grown endodontic biofilms. Earlygrown biofilms may not represent the complexity and maturity of biofilms found inside the oral cavity. The lack of laboratory models that mimic the clinical scenarios may not result in reliable outcomes [49]. Therefore, the use of mature biofilms grown for an extended time (proximally 21 days) is recommended [50]. In an earlier investigation, 30-day E. faecalis biofilms grown inside extracted teeth were treated with aPDT [50]. The outcome of the aPDT (MB; $25 \mu \mathrm{g} / \mathrm{mL}$ ) was similar to conventional irrigation [50].

\section{5. aPDT Performance in Clinical Studies}

Evidence-based dentistry guides dentists to integrate clinical judgment and the patient's values with the best available evidence. Overall, the existing literature on aPDT performance can be categorized as studies that have a randomized experimental design. For this review, we searched for keywords and subject terms related to randomized clinical studies that evaluated the antibacterial effects of aPDT against endodontic pathogens. Two independent reviewers (R.A.A. and A.A.B) performed the searches, using PubMed, MEDLINE, SCOPUS, and EMBASE databases. Table 2 and Box 1 demonstrate a summary of the randomized clinical trials investigating the role of aPDT in root canal disinfection. The following search strategy was used: "((photodynamic therapies) OR photodynamic OR Photochemotherapy) AND (endodontic* OR (root canal)) AND ((case control) OR (clinical trial) $O R$ (in vivo))". Previously published reviews about this theme were also assessed to look for cross-references about in vivo studies. Grey literature was also reviewed. A total of 205 studies were extracted. After removing the duplicates and reading the abstracts, 27 articles were eligible for full-text evaluation. The inclusion criteria include the randomized clinical trials that used aPDT for endodontic disinfection. Articles with no clear randomization approach or those that used only a light therapy without PSs were excluded. After the full-text evaluation, only seven randomized clinical trials were included (Table 1). 
Table 2. Summary of the randomized clinical trials reporting aPDT outcomes against endodontic infections.

\begin{tabular}{|c|c|c|c|c|c|}
\hline Author & Target Tooth & PS & Light Parameters & Protocol & Main Outcome \\
\hline $\begin{array}{l}\text { Ahangari Z } \\
\text { et al. (2017) [51] }\end{array}$ & $\begin{array}{l}\text { Root canal treated } \\
\text { molars with } \\
\text { periapical lesion }\end{array}$ & $\begin{array}{c}\mathrm{MB} \\
(50 \mathrm{mg} / \mathrm{mL})\end{array}$ & $\begin{array}{c}\text { Diode laser } \\
(808 \mathrm{~nm} ; 0.2 \mathrm{~W})\end{array}$ & $\begin{array}{l}\text { The PS intracanal } \\
\text { application; } 5 \mathrm{~min}+ \\
10 \text { s irradiation }\end{array}$ & $\begin{array}{l}\text { Both aPDT and calcium } \\
\text { hydroxide therapies significantly } \\
\text { reduced the CFUs counts of } E \text {. } \\
\text { faecalis and C. albicans, with no } \\
\text { significant difference between the } \\
\text { two approaches. }\end{array}$ \\
\hline $\begin{array}{l}\text { Asnaashari M } \\
\text { et al. (2017) [52] }\end{array}$ & $\begin{array}{l}\text { Root canal treated } \\
\text { molars with } \\
\text { periapical lesion but } \\
\text { with no existing pain, } \\
\text { swelling, or any } \\
\text { systematic diseases }\end{array}$ & $\begin{array}{c}\mathrm{TBO} \\
(0.1 \mathrm{mg} / \mathrm{mL})\end{array}$ & $\begin{array}{c}\text { Red LED } \\
(630 \mathrm{~nm} ; 2-4 \mathrm{~mW} \\
\left.1.2-4.4 \mathrm{~J} / \mathrm{cm}^{2}\right)\end{array}$ & $\begin{array}{l}\text { The PS intracanal } \\
\text { application; } 5 \mathrm{~min}+ \\
60 \mathrm{~s} \text { irradiation }\end{array}$ & $\begin{array}{l}\text { The microbiological sampling } \\
\text { revealed that aPDT could } \\
\text { disinfect the canals in a single } \\
\text { visit. aPDT was associated with a } \\
\text { lower number of colonies } \\
\text { compared to the calcium } \\
\text { hydroxide group. }\end{array}$ \\
\hline $\begin{array}{l}\text { Rabello DGD } \\
\text { et al. (2017) [53] }\end{array}$ & $\begin{array}{l}\text { Root canal treated } \\
\text { teeth (single root) } \\
\text { with apical } \\
\text { periodontitis }\end{array}$ & $\begin{array}{c}\mathrm{MB} \\
(0.1 \mathrm{mg} / \mathrm{mL})\end{array}$ & $\begin{array}{l}\text { Diode Laser } \\
(660 \mathrm{~nm} ; 60 \mathrm{~mW} \\
\left.129 \mathrm{~J} / \mathrm{cm}^{2}\right)\end{array}$ & $\begin{array}{l}\text { The PS intracanal } \\
\text { application; } 1 \text { min }+ \\
2 \text { min irradiation }\end{array}$ & $\begin{array}{l}\text { In the single-visit treatment, aPDT } \\
\text { significantly reduced the bacterial } \\
\text { load inside the root canals.In the } \\
\text { two-visit treatment, aPDT was } \\
\text { used following calcium } \\
\text { hydroxide, and no additional } \\
\text { benefits from using the aPDT } \\
\text { were observed. Using the aPDT } \\
\text { did not complement the reduction } \\
\text { of endotoxins inside the canals, } \\
\text { while calcium hydroxide therapy } \\
\text { was significantly reduced. }\end{array}$ \\
\hline $\begin{array}{l}\text { da Silva C.C. } \\
\text { et al. (2018) [54] }\end{array}$ & $\begin{array}{l}\text { Non-treated } \\
\text { single-rooted teeth } \\
\text { diagnosed with } \\
\text { necrotic pulp and } \\
\text { apical periodontitis }\end{array}$ & $\begin{array}{c}\mathrm{MB} \\
(100 \mu \mathrm{g} / \mathrm{mL})\end{array}$ & $\begin{array}{l}\text { Indium-gallium- } \\
\text { aluminum- } \\
\text { phosphide laser } \\
(660 \mathrm{~nm} ; 100 \mathrm{~mW} \\
\left.7 \mathrm{~J} / \mathrm{cm}^{2}\right)\end{array}$ & $\begin{array}{c}\text { The PS intracanal } \\
\text { application; } 5 \text { min }+ \\
2 \times 40 \text { s irradiation at } \\
\text { the apical level } \\
+1 \times 30 \text { s irradiation } \\
\text { By light tip } \\
\text { movement }\end{array}$ & $\begin{array}{c}\text { aPDT was associated with } \\
\text { significant } E \text {. faecalis inhibition at } \\
\text { the second visit. }\end{array}$ \\
\hline $\begin{array}{l}\text { de Mirandaand } \\
\text { Colombo (2018) [55] }\end{array}$ & $\begin{array}{l}\text { Non- treated molars } \\
\text { diagnosed with pulp } \\
\text { necrosis and } \\
\text { radiographic apical } \\
\text { periodontitis }\end{array}$ & $\begin{array}{c}\mathrm{MB} \\
(25 \mu \mathrm{g} / \mathrm{mL})\end{array}$ & $\begin{array}{c}\text { Diode laser } \\
(660 \mathrm{~nm} ; 100 \mathrm{~mW})\end{array}$ & $\begin{array}{l}\text { The PS intracanal } \\
\text { application; } 5 \text { min }+ \\
5 \text { min irradiation }\end{array}$ & $\begin{array}{l}\text { Both aPDT and conventional } \\
\text { therapies promoted an increase in } \\
\text { periapical healing over time, but } \\
\text { aPDT resulted in better healing at } \\
\text { 6-month follow-up compared to } \\
\text { conventional endodontic } \\
\text { treatment alone. }\end{array}$ \\
\hline $\begin{array}{l}\text { Barciela B. } \\
\text { et al. (2019) [56] }\end{array}$ & $\begin{array}{l}\text { Non-treated } \\
\text { single-rooted teeth } \\
\text { diagnosed with } \\
\text { necrotic pulp and } \\
\text { apical periodontitis }\end{array}$ & $\begin{array}{c}\mathrm{MB} \\
(0.5 \mathrm{mg} / \mathrm{mL})\end{array}$ & $\begin{array}{l}\text { Diode laser } \\
(660 \mathrm{~nm} ; \\
\left.320 \mathrm{~J} / \mathrm{cm}^{2}\right)\end{array}$ & $\begin{array}{l}\text { The PS intracanal } \\
\text { application; } 5 \mathrm{~min}+ \\
90 \text { s irradiation }\end{array}$ & $\begin{array}{l}\text { The post-operative pain between } \\
\text { aPDT and conventional } \\
\text { endodontic treatment was similar. }\end{array}$ \\
\hline $\begin{array}{l}\text { Coelho M.S. } \\
\text { et al. (2019) [57] }\end{array}$ & $\begin{array}{l}\text { Non-treated } \\
\text { single-rooted teeth } \\
\text { diagnosed with } \\
\text { necrotic pulp }\end{array}$ & $\begin{array}{c}\mathrm{MB} \\
(1.56 \\
\mu \mathrm{M} / \mathrm{mL})\end{array}$ & $\begin{array}{l}\mathrm{CO}_{2} \text { or ND:Yag } \\
(660 \mathrm{~nm} ; 100 \mathrm{~mW} \\
\left.600 \mathrm{~J} / \mathrm{cm}^{2}\right)\end{array}$ & $\begin{array}{l}\text { The PS intracanal } \\
\text { application; } 2 \text { min }+ \\
3 \text { min irradiation }\end{array}$ & $\begin{array}{l}\text { aPDT was efficient in reducing } \\
\text { post-operative pain in single-visit } \\
\text { root canal treatment of teeth with } \\
\text { necrotic pulps. }\end{array}$ \\
\hline
\end{tabular}

Box 1. Summary of aPDT PS and light sources found in the in vitro studies.

- $\quad$ Phenothiazine photosensitizers, mostly methylene blue (MBO) is the chosen PS.

- $\quad$ The concentrations of MB range from 25 to $100 \mu \mathrm{g} / \mathrm{mL}$.

- Toluidine blue ortho (TBO) at $0.1 \mathrm{mg} / \mathrm{mL}$ concentration was used for one study.

- The most frequently used light source was a diode laser at $660 \mathrm{~nm}$.

- $\quad$ Energy doses range from 1.4 to $200 \mathrm{~J} / \mathrm{cm}^{2}$.

In a clinical trial by Ahangari et al., a significant inhibition against E. faecalis and Candida albicans was reached when aPDT was performed using $\mathrm{MB}$ at $50 \mathrm{mg} / \mathrm{mL}$ and diode laser ( $810 \mathrm{~nm} ; 0.2 \mathrm{~W}$ power) delivered by a $200 \mu \mathrm{m}$-diameter end tip [51]. After root canal instrumentation and irrigation, bacterial biofilm samples were taken. Then, in the aPDT group, $0.5 \mathrm{~mL}$ of methylene blue was placed inside the canals for $5 \mathrm{~min}$, followed by 
$10 \mathrm{~s}$ irradiation. The canals were irrigated again, and another bacterial sample was taken. In the other group, $\mathrm{Ca}(\mathrm{OH})_{2}$ was used as an intracanal medicament for seven days, and then another bacterial sample was taken. Both approaches revealed significant inhibition against $E$. faecalis and C. albicans with no significant difference between them. This report was among the first studies to investigate the effect of aPDT in endodontics in vivo.

Similarly, the use of TBO $(0.1 \mathrm{mg} / \mathrm{mL})$ to treat molars with periapical infections was also attempted by Asnaashari et al. [52]. The design was similar to the previous study, where aPDT was compared to $\mathrm{Ca}(\mathrm{OH})_{2}$. However, in this study, the TBO was incubated for $5 \mathrm{~min}$ and irradiated for another $1 \mathrm{~min}$ with an energy density of $1.2-4.4 \mathrm{~J} / \mathrm{cm}^{2}$ and light intensity of $2.4 \mathrm{~mW}$, using LED light. At the same time, the $\mathrm{Ca}(\mathrm{OH})_{2}$ was placed for two weeks. The microbiological results revealed that both interventions were effective in eliminating the bacterial biofilms [52]. The results suggested the benefit of aPDT in minimizing the number of endodontic treatment visits. However, long-term evaluation to monitor the periapical infections around the apex may provide more critical information.

The combinatory effect of aPDT and $\mathrm{Ca}(\mathrm{OH})_{2}$ was investigated to illustrate if a synergetic effect was evident [53]. Following the chemo-mechanical debridement, teeth were either treated in a single visit using aPDT or in two visits, using $\mathrm{Ca}(\mathrm{OH})_{2}$ medication for 14 days followed by aPDT treatment. The aPDT protocol involved the use of $0.1 \mathrm{mg} / \mathrm{mL}$ of MB incubated inside the canal for $1 \mathrm{~min}$ and then irradiated for $2 \mathrm{~min}$, using a light intensity of $60 \mathrm{~mW}$ and an energy density of $129 \mathrm{~J} / \mathrm{cm}^{2}$. In the one-visit group, bacterial samples were isolated before and after the chemo-mechanical preparation and after the aPDT treatment. In the two-visit group, bacterial samples were isolated at four time points: (i) before the treatment, (ii) after the chemo-mechanical preparation, (iii) after the $\mathrm{Ca}(\mathrm{OH})_{2}$ medication, and (v) after the aPDT treatment.

Both approaches significantly reduced the bacterial load following the chemo- mechanical debridement. It worth noting that the bacterial reduction obtained with aPDT treatment in the one-visit group was equivalent to that found after $\mathrm{Ca}(\mathrm{OH})_{2}$ application. The supplementary aPDT following the $\mathrm{Ca}(\mathrm{OH})_{2}$ application did not increase the bacterial reduction or endotoxins' content. These results may emphasize the ability of aPDT to minimize the number of endodontic visits.

The adjunctive use of aPDT following the $\mathrm{Ca}(\mathrm{OH})_{2}$ medication was found significant in reducing the counts of E. faecalis, compared to the use of $\mathrm{Ca}(\mathrm{OH})_{2}$ alone [54]. In this study, MB $100 \mu \mathrm{g} / \mathrm{mL}$ was incubated for $5 \mathrm{~min}$ and then activated via an indium-, gallium-, and aluminum-phosphide laser (InGaAIP) for a total of $70 \mathrm{~s}$ with a total energy density of $7 \mathrm{~J} / \mathrm{cm}^{2}$. In another investigation, endodontic treated teeth were observed six months after the intervention [55]. Teeth diagnosed with pulp necrosis and periapical periodontitis were treated with either $\mathrm{Ca}(\mathrm{OH})_{2}$ medications, kept for 7-10 days with or without supplemental aPDT. The aPDT protocol involved the use of $0.5 \mathrm{~mL}$ of MB $25 \mu \mathrm{g} / \mathrm{mL}$, incubated inside the canal for $5 \mathrm{~min}$ followed by $5 \mathrm{~min}$ of irradiation time via diode laser. Using radiographic evaluation by observing the tissues around the treated teeth apex, aPDT was significantly associated with improved healing than the conventional endodontic therapy using the $\mathrm{Ca}(\mathrm{OH})_{2}$ medication. No significant difference in the microbial sampling was found between the two groups. This study was unique for being the first study to perform long-term evaluation following aPDT [55].

Our search also reveals contradicting outcomes. To date, only two investigations have focused on post-operative pain as an outcome after aPDT endodontic disinfection. While one clinical report concluded that no additional benefit is associated with using aPDT to reduce post-operative pain [56], the other showed that using aPDT was effectively significant [57]. Both studies used MB as a PS; however, variation in the parameters may suggest a divergent outcome.

From the perspective of bacterial reduction, five of the seven clinical studies, found in Table 1, reported a positive outcome for aPDT against endodontic pathogens. Four of the five used MB as a PS with different concentrations ranged between 0.025 and $50 \mathrm{mg} / \mathrm{mL}$ [51,53-55], and one study used TBO at a concertation of $0.1 \mathrm{mg} / \mathrm{mL}$ [52]. The 
study that used the highest methylene blue concentration $(50 \mathrm{mg} / \mathrm{mL})$ reported that no additional effect could be obtained from using aPDT for disinfection [51]. It is critical to observe here that the irradiation time was low (10 s), which may affect the dosimetry of the aPDT. Opposingly, the other three studies using methylene blue used low concentrations, but the time of irradiation was increased, resulting in some positive outcomes because of using aPDT intervention. Some of the studies did not report the amount of energy density, explaining the results more difficult as the aPDT effect depends on the dosimetry of aPDT [33].

Considering aPDT dosimetry, it was critical to observe how these studies reported energy density delivered to the target area. In the reported studies, fiber optics were used to irradiate the canal's working length level. Logically, the light distribution among the fiber is not similar, resulting in different energy density values at various locations inside the root canal system. Only one study reported the energy density dose as a range [52].

Some of the reported studies applied aPDT as an independent intervention [51,52]. It is also essential to consider aPDT as an adjunctive treatment. More importantly, future studies may attempt to explore the standardization of aPDT dosimetry and new strategies to enhance the disinfection outcomes.

\section{Nanostructures-Based Photosensitizers (PSs) to Overcome the Drawback of Conventional Endodontic Therapy: Present and Future Approaches}

Bio-nanotechnology has opened new avenues for aPDT. Two significant shortcomings of the current phototherapeutic interventions for the disinfection of root canals are the restricted penetration of photosensitizer (PS) and light propagation inside the dentinal tubules [36]. Extensive laboratory studies have shown that an essential aspect of this therapy is that the two components, when used independently, produce no effect on bacteria or healthy tissue. It is only the combination of PS and light that affects the bacteria [33].

Facing the paucity of delivery strategies to target sites, advances in photonanomedicine strategies have conveyed optimization and feasibility of the clinical outcomes of photodynamic therapy in medicine and biotechnology [58]. Nanoparticles associated with aPDT have greatly enhanced bacterial disinfection outcomes. Nanoparticles (1-100 nm in size) represent emergent PS carriers that show great promise for aPDT. They present the three dimensions in nanoscale and can be organic, inorganic, or combined [59]. Among these structures, polymeric-based nanocapsules and nanospheres and metallic and oxide nanoparticles can be found.

In endodontics, the use of nanoparticles for aPDT has also gained interest. Conventional aPDT, as aforementioned, is based on the use of biocompatible PS applied in a specific site and photoactivated to generate ROS, decreasing microorganisms' viability. MB and TBO are well-recognized PS due to their lack of cytotoxicity and targeting ability against Gram-positive and Gram-negative bacteria [60]. However, the incomplete destruction of biofilms along the root canal using MB as the main PS has boosted the search for enhanced strategies. In this context, nanoparticles can be used as active PS because of their diverse design and increased penetration capacity within biofilms. Different nanoparticle-based PS strategies may be classified, as shown in Figure 5 [61].

Nanoparticle-based PS present many advantages over free photosensitizing molecules. As pointed out by the growing literature [62], the conjugation of nanoparticles with PS significantly improves aPDT effects; this theme is addressed in this review. The most remarkable strategies where nanotechnology is applied to PS are discussed here. Mainly, the use of PS loaded in polymeric nanoparticles, nanoparticles as an active PS, PS in nanoemulsions, quantum dots and nanodiamond roles, and magnetic nanoparticles conjugated with PS are summarized in Box 2. 


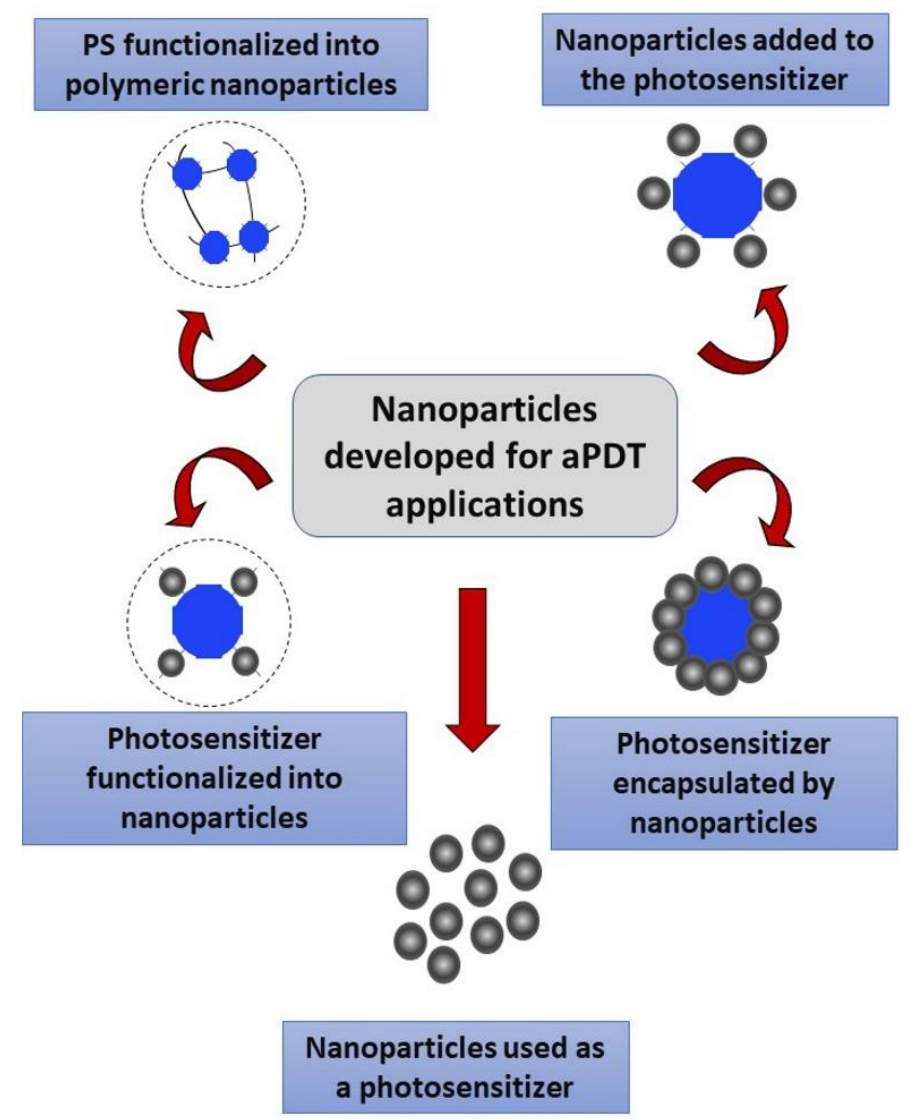

Figure 5. Most remarkable strategies where nanotechnology is applied to PS to enhance the aPDT disinfection outcomes.

\subsection{PS Loaded in Polymeric Nanoparticles}

The use of polymeric materials as therapeutic carriers is well-established in the literature. Because of their unique properties and designs, such as low cytotoxicity and excellent permeability $[63,64]$, polymeric nanoparticles have been used as carriers for antimicrobial and anti-cancer therapeutic agents $[65,66]$. In dentistry, polymeric compounds construct dental appliances, resin-based materials, and tissue engineering carriers [67,68]. Several polymeric nanoparticles have been conjugated with PS to improve the performance of aPDT. The most used polymers are chitosan and polylactic-co-glycolic (PLGA). These polymers' cationic nanoparticles can interact effectively with the negatively charged bacterial membrane, inducing nanoholes on the membrane, resulting in bacterial death [36].

In one study, $\mathrm{TBO}$ and chitosan polymeric nanoparticles were functionalized to inhibit E. faecalis biofilm inside the root canal system. aPDT treatment resulted in a biofilm inhibition similar to the $\mathrm{NaOCl}$ irrigation and the use of chitosan alone. However, conjugating the TBO and chitosan resulted in significant and increased inhibition, compared to each treatment alone [69]. Chitosan was also functionalized with rose bengal to target E. faecalis and Pseudomonas aeruginosa biofilms. At the energy density of $60 \mathrm{~J} / \mathrm{cm}^{2}$, the chitosan-rose Bengal conjugation achieved significant inhibition with a 7-log reduction in E. faecalis biofilm compared to 5-log when rose bengal was used alone. In P. aeruginosa biofilms, the conjugation resulted in complete eradication of the biofilms [70]. The conjugation of PLGA and methylene blue resulted in a 2-log reduction in E. faecalis biofilm [71].

More investigations are needed to optimize and validate the use of polymeric nanoparticles in aPDT against endodontic pathogens. Future investigations may focus on using ex vivo models where the biofilm must be initiated inside the root canal system for several days. Conducting such experiments may provide more information about the benefits of polymeric nanocarriers in endodontic treatment. 
Box 2. The benefits of nanoparticle-based photosensitizers.

- Higher PS per mass content can be achieved when PS are conjugated with nanoparticles, leading to a higher ROS production.

- $\quad$ Reduced ability of the target microorganism to pump molecules out of the cell, which leads to reduced resistance against agents.

- Prospect of targeting the microorganisms due to the improved relationship between nanoparticles and bacteria because of the electronic charge of nanoparticles surfaces.

- The PS achieve higher stability when combined with nanoparticles.

- Lower physical quenching due to PS aggregation. Most PS form aggregates in the aqueous medium when they are in their free form, leading to self-quenching when they are excited and reduced ROS generation.

- $\quad$ Possibility of controlled release of ROS after photoactivation.

\subsection{Nanoparticles as an Active PS}

Nanoparticles themselves can act as PS via the generation of ROS when photoexcited. Titanium dioxide $\left(\mathrm{TiO}_{2}\right)$, zinc oxide $(\mathrm{ZnO})$, and fullerenes nanoparticles produce reactive species, such as singlet oxygen, depending on the wavelength irradiated over them [61]. The crystalline structure of the materials influences the ROS generation. For instance, when rutile and anatase $\left(\mathrm{TiO}_{2}\right.$ crystalline structures) were compared, the following order and quantity of generated ROS were observed: anatase, a wavelength at $365 \mathrm{~nm}>$ rutile, at $405 \mathrm{~nm}>$ rutile, at $365 \mathrm{~nm}>$ anatase, at $405 \mathrm{~nm}$ [72]. Despite the possibility of using these particles alone to generate ROS with photoactivation, most of the studies conjugate organic PS with the nanoparticles, such as $\mathrm{ZnO}$ with crystal violet [73] or silver with TBO [74]. There is a lack of literature concerning the use of such particles as active PS. Further investigations could be performed to investigate the cytotoxic and antibacterial effects of nanoparticles as an active PS, with or without another PS conjugation.

\subsection{PS in Nanoemulsions}

A method to carry the PS in photodynamic therapy is in nanoemulsions. Nanoemulsions are "thermodynamically stable colloidal dispersions composed of two immiscible liquids" [75,76]. In nanoemulsions, one of the liquids is presented as a small droplet with a range size inferior to $100 \mathrm{~nm}$ dispersed within the other liquid [76]. This approach is currently explored to carry hydrophobic drugs and PS in an aqueous biological environment [77]. Moreover, the oil-based nanoemulsions present antimicrobial activity because of the hydrophobic character and interaction with the phospholipid bilayer of bacterial membranes [75].

Positively and negatively charged nanoemulsions composed of chloro-aluminum phthalocyanine were tested against Staphylococcus aureus in biofilm and planktonic forms. Promising antibacterial activity outcomes were achieved when the positively charged nanoemulsion composed of chloro-aluminum phthalocyanine was used at $31.8 \mu \mathrm{M}$ and a wavelength at $660 \mathrm{~nm}$ was applied for $26 \mathrm{~min}$ [78].

The effect of nanoemulsions composed of clove oil and zinc phthalocyanines against E. faecalis and methicillin-resistant S. aureus (MRSA) light-irradiation was attempted to improve aPDT effectiveness [79]. Zinc phthalocyanines present great photobiological activity to be applied in photodynamic therapy. However, they are not miscible with aqueous solutions, which make their handling difficult. The maximum zinc phthalocyanines loaded was $5 \%$ and clove oil, $5 \%$, resulting in a nanoemulsion of $30 \mathrm{~nm}$ and maintaining the drop size as lower than $50 \mathrm{~nm}$. The minimum inhibitory concentration against E. faecalis was $1.09 \mu \mathrm{g} / \mathrm{mL}$ and $0.065 \mu \mathrm{g} / \mathrm{mL}$ against MRSA. When zinc phthalocyanine was within the nanoemulsion, there was higher antibacterial activity than free zinc phthalocyanine. Moreover, as aforementioned, nanoemulsions can present antibacterial activity due to their hydrophobicity. In this study, blank nanoemulsions also presented antibacterial activity [79]. 


\subsection{Quantum Dots in Antimicrobial Photodynamic Therapy}

Quantum dots are nanocrystals created from semiconductors and are readily synthesized by processes of self-organization of particles, such as sol-gel [80,81]. Their nano dimension of up to $10 \mathrm{~nm}$ confer to them unique optical features and influence their fluorescence wavelength. Moreover, these particles have a high photostability [82]. The fluorescence of quantum dots is greatly attributed to their smaller size more so than the exciton Bohr radius. The exciton Bohr radius is the distance between the electron-hole pair. When the particle's radius is smaller than the electron-hole pair, quantum confinement occurs [83]. The random switching of bright and dark, a usual behavior of quantum dots, was observed by the fluorescence microscopy due to illumination-induced charging (on off). Simultaneously, a non-radiative Auger recombination predominates, and the reneutralization period (off, on) occurs while radiative recombination prevails [84,85]. This switching effect is observed as a photoemission blinking, which was also indicated when zinc oxide quantum dots were incorporated into experimental adhesives for therapeutic purposes [80].

Quantum dots of tantalum oxide [86], zinc oxide [87], and titanium dioxide [88] (oxides that may show bioactivity) were already synthesized and incorporated into dental materials to provide antibacterial activity. CdSe/ZnS core-shell quantum dots were also incorporated in a resin to tailor dental composites' fluorescence [89]. In recent years, quantum dots have emerged as novel PS in photodynamic therapies [82] due to the aforementioned optical properties. An interesting approach is based on the quantum dots' ability to carry antibiotics, proteins, drugs to combat tumors, and other biomolecules beyond the fluorescence property [82].

Despite the increased bioengineering application, these particles are poorly investigated in photodynamic therapy for disinfection purposes. In 2019, graphene quantum dots doped with curcumin, a natural PS extracted from turmeric roots, were tested against periodontal pathogens mixed biofilms [90]. The particles were irradiated (435 nm for $1 \mathrm{~min}$ ), and the quantity of ROS formed, as well as the biofilm-formation ability and the changes in gene expressions implicated in the biofilm formation, were evaluated. As an outcome, the photoexcited particles showed antimicrobial activity against planktonic and biofilm forms and regulated the gene expression, evidencing a great alternative PS against perio-pathogens [90].

Moreover, photoactivable polymers with cadmium quantum dots conjugated with crystal violet were tested against important clinical multidrug-resistant bacteria: methicillinresistant S. aureus and a carbapenemase-producing strain of Escherichia coli [91]. Crystal violet was added in this study to improve ROS generation. The analyzed photoluminescence lifetime and the ROS generation showed a chemical interaction between the crystal violet and the quantum dots. Furthermore, the particles evidenced great antimicrobial activity against these strains [91]. So far, none of the quantum dots strategies have been investigated in the endodontics field for proof of concept. However, quantum dots seem to be a promising approach to treat biofilms along the root canal due to their ability to be functionalized, conjugate with other drugs, penetrate through narrow canals, emit electromagnetic energy, and be identified via microscopic images.

\subsection{The Conjugates of PS and Nanodiamonds}

Nanodiamonds, also called diamond nanoparticles, are carbon-based nanomaterials. These particles have been highlighted in developing platforms for delivery agents, as shown in Figure 6. Their fluorescence favors their application for photodynamic purposes [92,93]. Defective sites are generated on nanodiamond surfaces when treated with acids, conferring them high photostability during fluorescence. Nanodiamonds were initially investigated to improve the mechanical properties of polymethyl methacrylate resin [94]. 


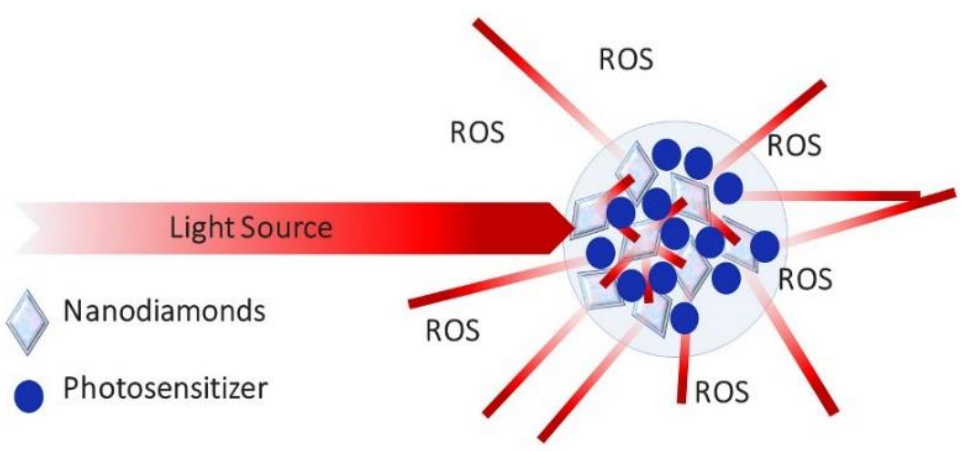

Figure 6. Schematic drawing of the promising conjugation of nanodiamonds with a photosensitizer to enhance aPDT disinfection. Nanodiamonds can act as photosensitizers by themselves, increasing the generation of reactive oxygen species and killing efficiency against biofilms.

Moreover, nanodiamonds have reported inherent antibacterial activity against key pathogen for dental caries, such as S. mutans [95]. In endodontics, nanodiamonds were incorporated into gutta-percha and showed activity against $S$. aureus when functionalized with amoxicillin [96]. This approach can be an exciting avenue to increase aPDT disinfection outcomes in constricted areas, such as the root canal, because of light scattering and ROS generation.

\subsection{The Conjugates of PS and Magnetic Nanoparticles}

Several investigations reported using magnetic nanoparticles and magnetic fields to improve the penetration capabilities of PS $[97,98]$. The conjugation of curcumin and iron oxide nanoparticles effectively enhanced the killing efficiency against cancer cells in vivo [99]. The same conjugation was investigated by Sun and colleagues for the elimination of periodontal pathogens [100]. The magnetic nanoparticles act as carriers for the PS, leading the PS to the core of biofilms when the magnetic field is applied. This strategy demonstrates the potential to improve PS penetrability through thick biofilms that could be difficult to be removed via conventional approaches [36]. No studies were reported concerning the use of magnetic fields and aPDT in endodontics. Exploring this field in the future may improve the clinical performance of aPDT in clinical use.

\subsection{The Conjugates of PS and Liposomes}

Liposomes are potential PSs carriers due to their biocompatibility [101]. They are lipid-based systems that can encapsulate hydrophobic and hydrophilic therapeutic agents within their hydrophobic bilayers to control their release and protect them from aggregation or degradation [101]. As most of the PSs are hydrophobic, using liposomes as carriers is advantageous [102]. Several investigations were conducted to implement liposomes in aPDT in dermatology and oncology $[103,104]$. Only in vitro investigations were conducted in dentistry to validate liposome integration with aPDT to target oral pathogens [105]. Liposomes functionalized into zinc phthalocyanine significantly reduced the growth of P. gingivalis [106]. Irradiating the E. faecalis biofilms, using 10 and $30 \mu \mathrm{M}$ of 5,10,15,20tetra(m-hydroxyphenyl)chlorin functionalized into liposomes resulted in around 5 to $7-\log$ reduction, while using $50 \mu \mathrm{M}$ of the same conjugation completely eradicated the E. faecalis biofilms [107]. 5,10,15,20-tetra(m-hydroxyphenyl)chlorin functionalized into liposomes was found effective in killing E. feacalis biofilms up to $300 \mu \mathrm{m}$ inside the dentinal tubules of root canal systems $[108,109]$. Future investigations may translate such a conjugation to a clinical model to evaluate its effectiveness, compared to conventional aPDT. 


\section{Concluding Remarks}

The effect of aPDT to disinfect root canal systems is well-described in the endodontic literature. aPDT is a promising approach to prevent reinfection without inducing bacterial resistance. However, the lack of specific protocols to use aPDT is a substantial barrier that may jeopardize the success of aPDT in endodontic disinfection. Further investigations may establish a reliable and effective protocol with excellent capabilities to induce clinical benefits in disinfecting the root canal system. Future studies may explore the use of different nano-platforms to improve the efficiency of aPDT as an adjunctive treatment in root canal therapy. Most of the PSs are hydrophobic with high susceptibility for aggregation and degradation in aqueous solutions. The use of nanotechnology to assist in overcoming limitations and enhance the stability, biocompatibility, and killing capabilities of PSs is a new era for aPDT, targeting oral biofilms.

Author Contributions: Conceptualization, R.A.A., I.M.G., A.A.B., F.M.C., F.C.M., and M.A.S.M.; discussions and literature reviews, R.A.A., I.M.G., A.A.B., F.M.C., F.C.M., and M.A.S.M.; writingoriginal draft preparation, R.A.A., F.C.M., and M.A.S.M.; writing-review and editing, F.C.M., and M.A.S.M. All authors have read and agreed to the published version of the manuscript.

Funding: This review manuscript was $\mathrm{f}$ by supported by IN-SPIRE Grant Program-University of Maryland School of Dentistry (M.M.S.M. and F.C.M.).

Institutional Review Board Statement: Not applicable.

Informed Consent Statement: Not applicable.

Conflicts of Interest: The authors declare no conflict of interest.

\section{References}

1. Martinho, F.C.; Gomes, B.P.F.A. Quantification of Endotoxins and Cultivable Bacteria in Root Canal Infection before and after Chemomechanical Preparation with 2.5\% Sodium Hypochlorite. J. Endod. 2008, 34, 268-272. [CrossRef]

2. Prada, I.; Micó-Muñoz, P.; Giner-Lluesma, T.; Micó-Martínez, P.; Collado-Castellano, N.; Manzano-Saiz, A. Influence of Microbiology on Endodontic Failure. Literature Review. Med. Oral Patol. Oral Cir. Bucal 2019, 24, e364-e372. [CrossRef] [PubMed]

3. Sjögren, U.; Figdor, D.; Persson, S.; Sundqvist, G. Influence of Infection at the Time of Root Filling on the Outcome of Endodontic Treatment of Teeth with Apical Periodontitis. Int. Endod. J. 1997, 30, 297-306. [CrossRef] [PubMed]

4. Marshall, J.G.; Walton, R.E. The Effect of Intramuscular Injection of Steroid on Posttreatment Endodontic Pain. J. Endod. 1984, 10, 584-588. [CrossRef]

5. Rosen, E.; Elbahary, S.; Haj-Yahya, S.; Jammal, L.; Shemesh, H.; Tsesis, I. The Invasion of Bacterial Biofilms into the Dentinal Tubules of Extracted Teeth Retrofilled with Fluorescently Labeled Retrograde Filling Materials. Appl. Sci. 2020, 10, 6996. [CrossRef]

6. Love, R.M. Enterococcus faecalis-A Mechanism for Its Role in Endodontic Failure. Int. Endod. J. 2001, 34, 399-405. [CrossRef]

7. Distel, J.W.; Hatton, J.F.; Gillespie, M.J. Biofilm Formation in Medicated Root Canals. J. Endod. 2002, 28, 689-693. [CrossRef]

8. Evans, M.; Davies, J.K.; Sundqvist, G.; Figdor, D. Mechanisms Involved in the Resistance of Enterococcus faecalis to Calcium Hydroxide. Int. Endod. J. 2002, 35, 221-228. [CrossRef]

9. Jett, B.D.; Huycke, M.M.; Gilmore, M.S. Virulence of Enterococci. Clin. Microbiol. Rev. 1994, 7, 462-478. [CrossRef]

10. Vivacqua-Gomes, N.; Gurgel-Filho, E.D.; Gomes, B.P.F.A.; Ferraz, C.C.R.; Zaia, A.A.; Souza-Filho, F.J. Recovery of Enterococcus faecalis after Single- or Multiple-Visit Root Canal Treatments Carried out in Infected Teeth Ex Vivo. Int. Endod. J. 2005, 38, 697-704. [CrossRef] [PubMed]

11. Waltimo, T.; Trope, M.; Haapasalo, M.; Ørstavik, D. Clinical Efficacy of Treatment Procedures in Endodontic Infection Control and One Year Follow-Up of Periapical Healing. J. Endod. 2005, 31, 863-866. [CrossRef] [PubMed]

12. Basrani, B.; Tjäderhane, L.; Santos, J.M.; Pascon, E.; Grad, H.; Lawrence, H.P.; Friedman, S. Efficacy of Chlorhexidine- and Calcium Hydroxide-Containing Medicaments against Enterococcus faecalis in Vitro. Oral Surg. Oral Med. Oral Pathol. Oral Radiol. Endod. 2003, 96, 618-624. [CrossRef]

13. Melo, M.A.; Rolim, J.P.; Zanin, I.C.; Silva, J.J.; Paschoal, A.R.; Ayala, A.P.; Rodrigues, L.K. A Comparative Study of the Photosensitizer Penetration into Artificial Caries Lesions in Dentin Measured by the Confocal Raman Microscopy. Photochem. Photobiol. 2014, 90, 183-188. [CrossRef] [PubMed]

14. Tang, G.; Samaranayake, L.P.; Yip, H.-K. Molecular Evaluation of Residual Endodontic Microorganisms after Instrumentation, Irrigation and Medication with Either Calcium Hydroxide or Septomixine. Oral Dis. 2004, 10, 389-397. [CrossRef] [PubMed]

15. Siqueira, J.F.; Guimarães-Pinto, T.; Rôças, I.N. Effects of Chemomechanical Preparation with 2.5\% Sodium Hypochlorite and Intracanal Medication with Calcium Hydroxide on Cultivable Bacteria in Infected Root Canals. J. Endod. 2007, 33, 800-805. [CrossRef] 
16. Peters, O.A.; Schönenberger, K.; Laib, A. Effects of Four Ni-Ti Preparation Techniques on Root Canal Geometry Assessed by Micro Computed Tomography. Int. Endod. J. 2001, 34, 221-230. [CrossRef]

17. Melo, M.A.; Rolim, J.P.; Passos, V.F.; Lima, R.A.; Zanin, I.C.; Codes, B.M.; Rocha, S.S.; Rodrigues, L.K. Photodynamic antimicrobial chemotherapy and ultraconservative caries removal linked for management of deep caries lesions. Photodiagnosis Photodyn Ther. 2015, 12, 581-586. [CrossRef]

18. Gomes, B.P.F.A.; Martinho, F.C.; Vianna, M.E. Comparison of 2.5\% Sodium Hypochlorite and 2\% Chlorhexidine Gel on Oral Bacterial Lipopolysaccharide Reduction from Primarily Infected Root Canals. J. Endod. 2009, 35, 1350-1353. [CrossRef]

19. Estrela, C.; Sydney, G.B.; Bammann, L.L.; Felippe Júnior, O. Mechanism of Action of Calcium and Hydroxyl Ions of Calcium Hydroxide on Tissue and Bacteria. Braz. Dent. J. 1995, 6, 85-90.

20. Siqueira, J.F.; Rôças, I.N.; Favieri, A.; Lima, K.C. Chemomechanical Reduction of the Bacterial Population in the Root Canal after Instrumentation and Irrigation with 1\%, 2.5\%, and 5.25\% Sodium Hypochlorite. J. Endod. 2000, 26, 331-334. [CrossRef]

21. Baras, B.H.; Melo, M.A.S.; Thumbigere-Math, V.; Tay, F.R.; Fouad, A.F.; Oates, T.W.; Weir, M.D.; Cheng, L.; Xu, H.H.K. Novel Bioactive and Therapeutic Root Canal Sealers with Antibacterial and Remineralization Properties. Materials 2020, $13,1096$. [CrossRef] [PubMed]

22. Souza, M.A.; Tumelero Dias, C.; Zandoná, J.; Paim Hoffmann, I.; Sanches Menchik, V.H.; Palhano, H.S.; Bertol, C.D.; RossatoGrando, L.G.; Cecchin, D.; de Figueiredo, J.A.P. Antimicrobial Activity of Hypochlorite Solutions and Reciprocating Instrumentation Associated with Photodynamic Therapy on Root Canals Infected with Enterococcus faecalis-An in Vitro Study. Photodiagnosis Photodyn. Ther. 2018, 23, 347-352. [CrossRef] [PubMed]

23. Orstavik, D.; Haapasalo, M. Disinfection by Endodontic Irrigants and Dressings of Experimentally Infected Dentinal Tubules. Endod. Dent. Traumatol. 1990, 6, 142-149. [CrossRef] [PubMed]

24. Fonzar, F.; Mollo, A.; Venturi, M.; Pini, P.; Fabian Fonzar, R.; Trullenque-Eriksson, A.; Esposito, M. Single versus Two Visits with 1-Week Intracanal Calcium Hydroxide Medication for Endodontic Treatment: One-Year Post-Treatment Results from a Multicentre Randomised Controlled Trial. Eur. J. Oral Implant. 2017, 10, $29-41$.

25. Erdem Hepsenoglu, Y.; Eyuboglu, T.F.; Özcan, M. Postoperative Pain Intensity after Single- versus Two-Visit Nonsurgical Endodontic Retreatment: A Randomized Clinical Trial. J. Endod. 2018, 44, 1339-1346. [CrossRef] [PubMed]

26. Shuping, G.B.; Ørstavik, D.; Sigurdsson, A.; Trope, M. Reduction of Intracanal Bacteria Using Nickel-Titanium Rotary Instrumentation and Various Medications. J. Endod. 2000, 26, 751-755. [CrossRef] [PubMed]

27. Abbott, P.V.; Hume, W.R.; Pearman, J.W. Antibiotics and Endodontics. Aust. Dent. J. 1990, 35, 50-60. [CrossRef]

28. WHO. World Health Organization Antimicrobial Resistance; World Health Organization: Geneva, Switzerland, 2014.

29. Tennert, C.; Feldmann, K.; Haamann, E.; Al-Ahmad, A.; Follo, M.; Wrbas, K.-T.; Hellwig, E.; Altenburger, M.J. Effect of Photodynamic Therapy (PDT) on Enterococcus faecalis Biofilm in Experimental Primary and Secondary Endodontic Infections. BMC Oral Health 2014, 14, 132. [CrossRef]

30. Abrahamse, H.; Hamblin, M.R. New Photosensitizers for Photodynamic Therapy. Biochem. J. 2016, 473, 347-364. [CrossRef]

31. Huang, L.; Xuan, Y.; Koide, Y.; Zhiyentayev, T.; Tanaka, M.; Hamblin, M. Type I and Type II Mechanisms of Antimicrobial Photodynamic Therapy: An in Vitro Study on Gram-Negative and Gram-Positive Bacteria. Lasers Surg. Med. 2012, 44, 490-499. [CrossRef]

32. Teófilo, M.Í.S.; de Carvalho Russi, T.M.A.Z.; de Barros Silva, P.G.; Balhaddad, A.A.; Melo, M.A.S.; Rolim, J.P.M.L. The Impact of Photosensitizers Selection on Bactericidal Efficacy Of PDT against Cariogenic Biofilms: A Systematic Review and Meta-Analysis. Photodiagnosis Photodyn. Ther. 2020, 102046. [CrossRef]

33. Balhaddad, A.A.; AlQranei, M.S.; Ibrahim, M.S.; Weir, M.D.; Martinho, F.C.; Xu, H.H.K.; Melo, M.A.S. Light Energy Dose and Photosensitizer Concentration Are Determinants of Effective Photo-Killing against Caries-Related Biofilms. Int. J. Mol. Sci. 2020, 21, 7612. [CrossRef] [PubMed]

34. Hardee, M.W.; Miserendino, L.J.; Kos, W.; Walia, H. Evaluation of the Antibacterial Effects of Intracanal Nd: YAG Laser Irradiation. J. Endod. 1994, 20, 377-380. [CrossRef]

35. Melo, M.A.S.; De-paula, D.M.; Lima, J.P.M.; Borges, F.M.C.; Steiner-oliveira, C.; Nobre-dos-santos, M.; Zanin, I.C.J.; Barros, E.B.; Rodrigues, L.K.A. In vitro photodynamic antimicrobial chemotherapy in dentine contaminated by cariogenic bacteria. Laser Phys. 2010, 20, 1-10. [CrossRef]

36. Balhaddad, A.A.; Garcia, I.M.; Ibrahim, M.S.; Rolim, J.P.M.L.; Gomes, E.A.B.; Martinho, F.C.; Collares, F.M.; Xu, H.; Melo, M.A.S. Prospects on Nano-Based Platforms for Antimicrobial Photodynamic Therapy Against Oral Biofilms. Photobiomodul. Photomed. Laser Surg. 2020, 38, 481-496. [CrossRef] [PubMed]

37. Zohre, R.; Ali, Y.; Mostafa, J.; Samaneh, R. Nondrug Antimicrobial Techniques: Electromagnetic Fields and Photodynamic Therapy. Biomed. Pharmacol. J. 2015, 8, 147-155. [CrossRef]

38. Plotino, G.; Grande, N.M.; Mercade, M. Photodynamic Therapy in Endodontics. Int. Endod. J. 2019, 52, 760-774. [CrossRef] [PubMed]

39. Melo, M.A.S. Photodynamic Antimicrobial Chemotherapy as a Strategy for Dental Caries: Building a More Conservative Therapy in Restorative Dentistry. Photomed. Laser Surg. 2014, 32, 589-591. [CrossRef]

40. Tavares, A.; Carvalho, C.M.B.; Faustino, M.A.; Neves, M.G.P.M.S.; Tomé, J.P.C.; Tomé, A.C.; Cavaleiro, J.A.S.; Cunha, A.; Gomes, N.C.M.; Alves, E.; et al. Antimicrobial Photodynamic Therapy: Study of Bacterial Recovery Viability and Potential Development of Resistance after Treatment. Mar. Drugs 2010, 8, 91-105. [CrossRef] 
41. Liu, Y.; Qin, R.; Zaat, S.A.J.; Breukink, E.; Heger, M. Antibacterial Photodynamic Therapy: Overview of a Promising Approach to Fight Antibiotic-Resistant Bacterial Infections. J. Clin. Transl. Res. 2015, 1, 140-167.

42. Pfitzner, A.; Sigusch, B.W.; Albrecht, V.; Glockmann, E. Killing of Periodontopathogenic Bacteria by Photodynamic Therapy. J. Periodontol. 2004, 75, 1343-1349. [CrossRef] [PubMed]

43. Chan, Y.; Lai, C.-H. Bactericidal Effects of Different Laser Wavelengths on Periodontopathic Germs in Photodynamic Therapy. Lasers Med. Sci. 2003, 18, 51-55. [CrossRef] [PubMed]

44. Seal, G.J.; Ng, Y.-L.; Spratt, D.; Bhatti, M.; Gulabivala, K. An in Vitro Comparison of the Bactericidal Efficacy of Lethal Photosensitization or Sodium Hyphochlorite Irrigation on Streptococcus Intermedius Biofilms in Root Canals. Int. Endod. J. 2002, 35, 268-274. [CrossRef] [PubMed]

45. Silva Garcez, A.; Núñez, S.C.; Lage-Marques, J.L.; Jorge, A.O.C.; Ribeiro, M.S. Efficiency of NaOCl and Laser-Assisted Photosensitization on the Reduction of Enterococcus faecalis in Vitro. Oral Surg. Oral Med. Oral Pathol. Oral Radiol. Endod. 2006, 102, e93-e98. [CrossRef] [PubMed]

46. Garcez, A.S.; Ribeiro, M.S.; Tegos, G.P.; Núñez, S.C.; Jorge, A.O.C.; Hamblin, M.R. Antimicrobial Photodynamic Therapy Combined with Conventional Endodontic Treatment to Eliminate Root Canal Biofilm Infection. Lasers Surg. Med. 2007, 39, 59-66. [CrossRef]

47. Foschi, F.; Fontana, C.R.; Ruggiero, K.; Riahi, R.; Vera, A.; Doukas, A.G.; Pagonis, T.C.; Kent, R.; Stashenko, P.P.; Soukos, N.S. Photodynamic Inactivation of Enterococcus faecalis in Dental Root Canals in Vitro. Lasers Surg. Med. 2007, 39, 782-787. [CrossRef]

48. Nunes, M.R.; Mello, I.; Franco, G.C.N.; de Medeiros, J.M.F.; Dos Santos, S.S.F.; Habitante, S.M.; Lage-Marques, J.L.; Raldi, D.P. Effectiveness of Photodynamic Therapy against Enterococcus faecalis, with and without the Use of an Intracanal Optical Fiber: An in Vitro Study. Photomed. Laser Surg. 2011, 29, 803-808. [CrossRef]

49. Saber, S.E.-D.M.; El-Hady, S.A. Development of an Intracanal Mature Enterococcus faecalis Biofilm and Its Susceptibility to Some Antimicrobial Intracanal Medications; an in Vitro Study. Eur. J. Dent. 2012, 6, 43-50.

50. Miranda, R.G.; Santos, E.B.; Souto, R.M.; Gusman, H.; Colombo, A.P.V. Ex Vivo Antimicrobial Efficacy of the EndoVac System plus Photodynamic Therapy Associated with Calcium Hydroxide against Intracanal Enterococcus faecalis. Int. Endod. J. 2013, 46, 499-505. [CrossRef]

51. Ahangari, Z.; Mojtahed Bidabadi, M.; Asnaashari, M.; Rahmati, A.; Tabatabaei, F.S. Comparison of the Antimicrobial Efficacy of Calcium Hydroxide and Photodynamic Therapy Against Enterococcus faecalis and Candida Albicans in Teeth with Periapical Lesions; An In Vivo Study. J. Lasers Med. Sci. 2017, 8, 72-78. [CrossRef]

52. Asnaashari, M.; Ashraf, H.; Rahmati, A.; Amini, N. A Comparison between Effect of Photodynamic Therapy by LED and Calcium Hydroxide Therapy for Root Canal Disinfection against Enterococcus faecalis: A Randomized Controlled Trial. Photodiagnosis Photodyn. Ther. 2017, 17, 226-232. [CrossRef] [PubMed]

53. Rabello, D.G.D.; Corazza, B.J.M.; Ferreira, L.L.; Santamaria, M.P.; Gomes, A.P.M.; Martinho, F.C. Does Supplemental Photodynamic Therapy Optimize the Disinfection of Bacteria and Endotoxins in One-Visit and Two-Visit Root Canal Therapy? A Randomized Clinical Trial. Photodiagnosis Photodyn. Ther. 2017, 19, 205-211. [CrossRef]

54. Da Silva, C.C.; Chaves Júnior, S.P.; Pereira, G.L.D.; Fontes, K.B.F.d.C.; Antunes, L.A.A.; Póvoa, H.C.C.; Antunes, L.S.; Iorio, N.L.P.P. Antimicrobial Photodynamic Therapy Associated with Conventional Endodontic Treatment: A Clinical and Molecular Microbiological Study. Photochem. Photobiol. 2018, 94, 351-356. [CrossRef]

55. De Miranda, R.G.; Colombo, A.P.V. Clinical and Microbiological Effectiveness of Photodynamic Therapy on Primary Endodontic Infections: A 6-Month Randomized Clinical Trial. Clin. Oral Investig. 2018, 22, 1751-1761. [CrossRef] [PubMed]

56. Barciela, B.; da Silva Limoeiro, A.G.; Bueno, C.E.; Fernandes, S.L.; Mandarini, D.R.; Boer, N.C.; Camara Fernandes, K.G.; Rocha, D.G. In Vivo Evaluation of Painful Symptomatology after Endodontic Treatment with or without the Use of Photodynamic Therapy. J. Conserv. Dent. 2019, 22, 332-335. [CrossRef] [PubMed]

57. Coelho, M.S.; Vilas-Boas, L.; Tawil, P.Z. The Effects of Photodynamic Therapy on Postoperative Pain in Teeth with Necrotic Pulps. Photodiagnosis Photodyn. Ther. 2019, 27. [CrossRef]

58. Hu, D.; Pan, M.; Yu, Y.; Sun, A.; Shi, K.; Qu, Y.; Qian, Z. Application of Nanotechnology for Enhancing Photodynamic Therapy via Ameliorating, Neglecting, or Exploiting Tumor Hypoxia. View 2020, 1, e6. [CrossRef]

59. Jeevanandam, J.; Barhoum, A.; Chan, Y.S.; Dufresne, A.; Danquah, M.K. Review on Nanoparticles and Nanostructured Materials: History, Sources, Toxicity and Regulations. Beilstein J. Nanotechnol. 2018, 9, 1050-1074. [CrossRef]

60. Harris, F.; Chatfield, L.K.; Phoenix, D.A. Phenothiazinium Based Photosensitisers-Photodynamic Agents with a Multiplicity of Cellular Targets and Clinical Applications. Curr. Drug Targets 2005, 6, 615-627. [CrossRef]

61. Kishen, A. Advanced Therapeutic Options for Endodontic Biofilms. Endod. Top. 2010, 22, 99-123. [CrossRef]

62. Shrestha, A.; Kishen, A. Antibacterial Nanoparticles in Endodontics: A Review. J. Endod. 2016, 42, 1417-1426. [CrossRef]

63. Abou Neel, E.A.; Bozec, L.; Perez, R.A.; Kim, H.-W.; Knowles, J.C. Nanotechnology in Dentistry: Prevention, Diagnosis, and Therapy. Int. J. Nanomed. 2015, 10, 6371-6394. [CrossRef]

64. Leung, K.C.-F.; Seneviratne, C.J.; Li, X.; Leung, P.C.; Lau, C.B.S.; Wong, C.-H.; Pang, K.Y.; Wong, C.W.; Wat, E.; Jin, L. Synergistic Antibacterial Effects of Nanoparticles Encapsulated with Scutellaria Baicalensis and Pure Chlorhexidine on Oral Bacterial Biofilms. Nanomaterials 2016, 6, 61. [CrossRef] [PubMed]

65. Guerrini, L.; Alvarez-Puebla, R.A.; Pazos-Perez, N. Surface Modifications of Nanoparticles for Stability in Biological Fluids. Materials 2018, 11, 1154. [CrossRef] [PubMed] 
66. Zamboni, C.G.; Kozielski, K.L.; Vaughan, H.J.; Nakata, M.M.; Kim, J.; Higgins, L.J.; Pomper, M.G.; Green, J.J. Polymeric Nanoparticles as Cancer-Specific DNA Delivery Vectors to Human Hepatocellular Carcinoma. J. Control. Release 2017, $263,18-28$. [CrossRef]

67. Balhaddad, A.A.; Kansara, A.A.; Hidan, D.; Weir, M.D.; Xu, H.H.K.; Melo, M.A.S. Toward Dental Caries: Exploring NanoparticleBased Platforms and Calcium Phosphate Compounds for Dental Restorative Materials. Bioact. Mater. 2019, 4, 43-55. [CrossRef] [PubMed]

68. Jazayeri, H.E.; Lee, S.-M.; Kuhn, L.; Fahimipour, F.; Tahriri, M.; Tayebi, L. Polymeric Scaffolds for Dental Pulp Tissue Engineering: A Review. Dent. Mater. 2020, 36, e47-e58. [CrossRef]

69. Camacho-Alonso, F.; Julián-Belmonte, E.; Chiva-García, F.; Martínez-Beneyto, Y. Bactericidal Efficacy of Photodynamic Therapy and Chitosan in Root Canals Experimentally Infected with Enterococcus faecalis: An In Vitro Study. Photomed. Laser Surg. 2017, 35, 184-189. [CrossRef] [PubMed]

70. Shrestha, A.; Kishen, A. Polycationic Chitosan-Conjugated Photosensitizer for Antibacterial Photodynamic Therapy. Photochem. Photobiol. 2012, 88, 577-583. [CrossRef]

71. Pagonis, T.C.; Chen, J.; Fontana, C.R.; Devalapally, H.; Ruggiero, K.; Song, X.; Foschi, F.; Dunham, J.; Skobe, Z.; Yamazaki, H.; et al Nanoparticle-Based Endodontic Antimicrobial Photodynamic Therapy. J. Endod. 2010, 36, 322-328. [CrossRef]

72. Takahashi, C.; Tsujimoto, Y.; Yamamoto, Y. The Effect of Irradiation Wavelengths and the Crystal Structures of Titanium Dioxide on the Formation of Singlet Oxygen for Bacterial Killing. J. Clin. Biochem. Nutr. 2012, 51, 128-131. [CrossRef] [PubMed]

73. Sehmi, S.K.; Noimark, S.; Pike, S.D.; Bear, J.C.; Peveler, W.J.; Williams, C.K.; Shaffer, M.S.P.; Allan, E.; Parkin, I.P.; MacRobert, A.J. Enhancing the Antibacterial Activity of Light-Activated Surfaces Containing Crystal Violet and ZnO Nanoparticles: Investigation of Nanoparticle Size, Capping Ligand, and Dopants. ACS Omega 2016, 1, 334-343. [CrossRef] [PubMed]

74. Aydın, H.; Er, K.; Kuştarcı, A.; Akarsu, M.; Gençer, G.M.; Er, H.; Felek, R. Antibacterial Activity of Silver Nanoparticles Activated by Photodynamic Therapy in Infected Root Canals. Dent. Med. Probl. 2020, 57, 393-400. [CrossRef]

75. Diogo, P.; F. Faustino, M.A.; P. M. S. Neves, M.G.; Palma, P.J.; P. Baptista, I.; Gonçalves, T.; Santos, J.M. An Insight into Advanced Approaches for Photosensitizer Optimization in Endodontics-A Critical Review. J. Funct. Biomater. 2019, 10, 44. [CrossRef] [PubMed]

76. McClements, D.J. Nanoemulsions versus Microemulsions: Terminology, Differences, and Similarities. Soft Matter 2012, 8, 1719-1729. [CrossRef]

77. Gutiérrez, J.M.; González, C.; Maestro, A.; Solè, I.; Pey, C.M.; Nolla, J. Nano-Emulsions: New Applications and Optimization of Their Preparation. Curr. Opin. Colloid Interface Sci. 2008, 13, 245-251. [CrossRef]

78. Ribeiro, A.P.D.; Andrade, M.C.; Bagnato, V.S.; Vergani, C.E.; Primo, F.L.; Tedesco, A.C.; Pavarina, A.C. Antimicrobial Photodynamic Therapy against Pathogenic Bacterial Suspensions and Biofilms Using Chloro-Aluminum Phthalocyanine Encapsulated in Nanoemulsions. Lasers Med. Sci. 2015, 30, 549-559. [CrossRef] [PubMed]

79. Schuenck-Rodrigues, R.A.; de Oliveira de Siqueira, L.B.; Dos Santos Matos, A.P.; da Costa, S.P.; da Silva Cardoso, V.; Vermelho, A.B.; Colombo, A.P.V.; Oliveira, C.A.; Santos-Oliveira, R.; Ricci-Júnior, E. Development, Characterization and Photobiological Activity of Nanoemulsion Containing Zinc Phthalocyanine for Oral Infections Treatment. J. Photochem. Photobiol. B 2020, 211, 112010. [CrossRef]

80. Garcia, I.M.; Leitune, V.C.B.; Kist, T.L.; Takimi, A.; Samuel, S.M.W.; Collares, F.M. Quantum Dots as Nonagglomerated Nanofillers for Adhesive Resins. J. Dent. Res. 2016, 95, 1401-1407. [CrossRef] [PubMed]

81. Meulenkamp, E.A. Synthesis and Growth of ZnO Nanoparticles. J. Phys. Chem. B 1998, 102, 5566-5572. [CrossRef]

82. Viana, O.S.; Ribeiro, M.S.; Fontes, A.; Santos, B.S. Quantum Dots in Photodynamic Therapy. In Redox-Active Therapeutics; Batinić-Haberle, I., Rebouças, J.S., Spasojević, I., Eds.; Oxidative Stress in Applied Basic Research and Clinical Practice; Springer International Publishing: Cham, Germany, 2016; pp. 525-539. ISBN 978-3-319-30705-3.

83. Zhang, Y.; Liu, Y.; Li, C.; Chen, X.; Wang, Q. Controlled Synthesis of Ag2S Quantum Dots and Experimental Determination of the Exciton Bohr Radius. J. Phys. Chem. C 2014, 118, 4918-4923. [CrossRef]

84. Xu, W.; Liu, W.; Schmidt, J.F.; Zhao, W.; Lu, X.; Raab, T.; Diederichs, C.; Gao, W.; Seletskiy, D.V.; Xiong, Q. Correlated Fluorescence Blinking in Two-Dimensional Semiconductor Heterostructures. Nature 2017, 541, 62-67. [CrossRef] [PubMed]

85. Efros, A.L.; Nesbitt, D.J. Origin and Control of Blinking in Quantum Dots. Nat. Nanotechnol. 2016, 11, 661-671. [CrossRef] [PubMed]

86. Garcia, I.M.; Souza, V.S.; Scholten, J.D.; Collares, F.M. Quantum Dots of Tantalum Oxide with an Imidazolium Ionic Liquid as Antibacterial Agent for Adhesive Resin. J. Adhes. Dent. 2020, 22, 207-214. [CrossRef]

87. Garcia, I.M.; Leitune, V.C.B.; Visioli, F.; Samuel, S.M.W.; Collares, F.M. Influence of Zinc Oxide Quantum Dots in the Antibacterial Activity and Cytotoxicity of an Experimental Adhesive Resin. J. Dent. 2018, 73, 57-60. [CrossRef] [PubMed]

88. Garcia, I.M.; Souza, V.S.; Hellriegel, C.; Scholten, J.D.; Collares, F.M. Ionic Liquid-Stabilized Titania Quantum Dots Applied in Adhesive Resin. J. Dent. Res. 2019, 98, 682-688. [CrossRef] [PubMed]

89. Alves, L.P.; Pilla, V.; Murgo, D.O.A.; Munin, E. Core-Shell Quantum Dots Tailor the Fluorescence of Dental Resin Composites. J. Dent. 2010, 38, 149-152. [CrossRef]

90. Pourhajibagher, M.; Parker, S.; Chiniforush, N.; Bahador, A. Photoexcitation Triggering via Semiconductor Graphene Quantum Dots by Photochemical Doping with Curcumin versus Perio-Pathogens Mixed Biofilms. Photodiagnosis Photodyn. Ther. 2019, 28, 125-131. [CrossRef] 
91. Owusu, E.G.A.; MacRobert, A.J.; Naasani, I.; Parkin, I.P.; Allan, E.; Yaghini, E. Photoactivable Polymers Embedded with Cadmium-Free Quantum Dots and Crystal Violet: Efficient Bactericidal Activity against Clinical Strains of Antibiotic-Resistant Bacteria. ACS Appl. Mater. Interfaces 2019, 11, 12367-12378. [CrossRef]

92. Hui, Y.Y.; Cheng, C.-L.; Chang, H.-C. Nanodiamonds for Optical Bioimaging. J. Phys. D Appl. Phys. 2010, 43, 374021. [CrossRef]

93. McGuinness, L.P.; Yan, Y.; Stacey, A.; Simpson, D.A.; Hall, L.T.; Maclaurin, D.; Prawer, S.; Mulvaney, P.; Wrachtrup, J.; Caruso, F.; et al. Quantum Measurement and Orientation Tracking of Fluorescent Nanodiamonds inside Living Cells. Nat. Nanotechnol. 2011, 6, 358-363. [CrossRef]

94. Protopapa, P.; Kontonasaki, E.; Bikiaris, D.; Paraskevopoulos, K.M.; Koidis, P. Reinforcement of a PMMA Resin for Fixed Interim Prostheses with Nanodiamonds. Dent. Mater. J. 2011, 30, 222-231. [CrossRef]

95. Cao, W.; Zhang, Y.; Wang, X.; Li, Q.; Xiao, Y.; Li, P.; Wang, L.; Ye, Z.; Xing, X. Novel Resin-Based Dental Material with Anti-Biofilm Activity and Improved Mechanical Property by Incorporating Hydrophilic Cationic Copolymer Functionalized Nanodiamond. J. Mater. Sci. Mater. Med. 2018, 29, 162. [CrossRef] [PubMed]

96. Lee, D.-K.; Kim, S.V.; Limansubroto, A.N.; Yen, A.; Soundia, A.; Wang, C.-Y.; Shi, W.; Hong, C.; Tetradis, S.; Kim, Y.; et al. Nanodiamond-Gutta Percha Composite Biomaterials for Root Canal Therapy. ACS Nano 2015, 9, 11490-11501. [CrossRef] [PubMed]

97. Rodrigues, G.R.; López-Abarrategui, C.; de la Serna Gómez, I.; Dias, S.C.; Otero-González, A.J.; Franco, O.L. Antimicrobial Magnetic Nanoparticles Based-Therapies for Controlling Infectious Diseases. Int. J. Pharm. 2019, 555, 356-367. [CrossRef] [PubMed]

98. Arruebo, M.; Fernández-Pacheco, R.; Ibarra, M.R.; Santamaría, J. Magnetic Nanoparticles for Drug Delivery. Nano Today 2007, 2, 22-32. [CrossRef]

99. Ashkbar, A.; Rezaei, F.; Attari, F.; Ashkevarian, S. Treatment of Breast Cancer in Vivo by Dual Photodynamic and Photothermal Approaches with the Aid of Curcumin Photosensitizer and Magnetic Nanoparticles. Sci. Rep. 2020, 10, 21206. [CrossRef]

100. Sun, X.; Wang, L.; Lynch, C.D.; Sun, X.; Li, X.; Qi, M.; Ma, C.; Li, C.; Dong, B.; Zhou, Y.; et al. Nanoparticles Having Amphiphilic Silane Containing Chlorin E6 with Strong Anti-Biofilm Activity against Periodontitis-Related Pathogens. J. Dent. 2019, 81, 70-84. [CrossRef]

101. Ghosh, S.; Carter, K.A.; Lovell, J.F. Liposomal Formulations of Photosensitizers. Biomaterials 2019, 218, 119341. [CrossRef]

102. Skupin-Mrugalska, P.; Piskorz, J.; Goslinski, T.; Mielcarek, J.; Konopka, K.; Düzgüneş, N. Current Status of Liposomal Porphyrinoid Photosensitizers. Drug Discov. Today 2013, 18, 776-784. [CrossRef]

103. Yang, Y.; Wang, L.; Cao, H.; Li, Q.; Li, Y.; Han, M.; Wang, H.; Li, J. Photodynamic Therapy with Liposomes Encapsulating Photosensitizers with Aggregation-Induced Emission. Nano Lett. 2019, 19, 1821-1826. [CrossRef] [PubMed]

104. Düzgüneş, N.; Piskorz, J.; Skupin-Mrugalska, P.; Goslinski, T.; Mielcarek, J.; Konopka, K. Photodynamic Therapy of Cancer with Liposomal Photosensitizers. Ther. Deliv. 2018, 9, 823-832. [CrossRef] [PubMed]

105. Longo, J.P.F.; Leal, S.C.; Simioni, A.R.; de Fátima Menezes Almeida-Santos, M.; Tedesco, A.C.; Azevedo, R.B. Photodynamic Therapy Disinfection of Carious Tissue Mediated by Aluminum-Chloride-Phthalocyanine Entrapped in Cationic Liposomes: An in Vitro and Clinical Study. Lasers Med. Sci. 2012, 27, 575-584. [CrossRef] [PubMed]

106. Ko, A.; Yee, M.; Skupin-Mrugalska, P.; Düzgünes, N. Photodynamic Therapy of Porphyromonas Gingivalis via LiposomeEncapsulated Sensitizers. J. Calif. Dent. Assoc. 2013, 41, 827-830. [PubMed]

107. Kranz, S.; Guellmar, A.; Völpel, A.; Gitter, B.; Albrecht, V.; Sigusch, B.W. Photodynamic Suppression of Enterococcus faecalis Using the Photosensitizer MTHPC. Lasers Surg. Med. 2011, 43, 241-248. [CrossRef] [PubMed]

108. Ossmann, A.; Kranz, S.; Andre, G.; Völpel, A.; Albrecht, V.; Fahr, A.; Sigusch, B.W. Photodynamic Killing of Enterococcus faecalis in Dentinal Tubules Using MTHPC Incorporated in Liposomes and Invasomes. Clin. Oral Investig. 2015, 19, 373-384. [CrossRef]

109. Ramos, U.D.; Suaid, F.; Wikesjö, U.M.E.; Susin, C.; Vital, P.C.; de Souza, S.L.S.; Messora, M.R.; Palioto, D.B.; Novaes, A.B. Microbiologic Effect of Two Topical Anti-Infective Treatments on Ligature-Induced Peri-Implantitis: A Pilot Study in Dogs. J. Periodontol. 2018, 89, 995-1002. [CrossRef] 